Analisis Faktor-Faktor yang Mempengaruhi Penggunaan E-Filing Oleh Wajib Pajak (Studi Pada Wajib Pajak Orang Pribadi yang Terdaftar pada KPP Madya dan Pratama di Kota Tangerang dan Tangerang Selatan)

\title{
ANALISIS FAKTOR-FAKTOR YANG MEMPENGARUHI PENGGUNAAN E-FILING OLEH WAJIB PAJAK
}

(Studi pada Wajib Pajak Orang Pribadi yang Terdaftar pada KPP Madya dan

Pratama di Kota Tangerang dan Tangerang Selatan)

\author{
Kathleen Wiratan \\ Universitas Multimedia Nusantara \\ keithwiratan11@gmail.com \\ Karina Harjanto \\ Universitas Multimedia Nusantara \\ karina.harjanto@umn.ac.id
}

\begin{abstract}
The purpose of this research is to analyze the influence of perceived usefulness, perceived ease of use, security and privacy, readiness of technology information, user's satisfaction towards the use of e-Filing. This research uses a primary data. Respondents are the individual taxpayers who report SPT Tahunan using e-Filing and register in the Tax Office (KPP) Madya and Pratama in Tangerang and South Tangerang City. There are 112 respondents in this study. The sampling technique used is convenience sampling. Data analysis in this research uses multiple linear regression with SPSS 25 Program.

The results of this study indicate that: (1) perceived usefulness has influence on the use of e-Filing, (2) perceived ease of use has influence on the use of e-Filing, (3) the security and privacy doesn't have influence on the use of e-Filing, (4) readiness technology information doesn't have influence on the use of e-Filing, (5) user's satisfaction has influence on the use of e-Filing, (6) perceived usefulness, perceived ease of use, security and privacy, readiness technology information, user's satisfaction have influence simultaneously on the use of eFiling.

Keywords: Perceived usefulness, perceived ease of use, security and privacy, readiness technology information, user's satisfaction, the use of e-Filing
\end{abstract}

\section{PENDAHULUAN}

Penerimaan pajak merupakan sumber pendapatan negara yang penting dan digunakan untuk melaksanakan dan membiayai seluruh pelaksanaan pembangunan serta pengeluaran rutin lainnya. Pajak merupakan sumber penerimaan negara yang terbesar di Indonesia saat ini. 
Tabel 1. Tren Penerimaan Pajak 2013-2017 (triliun Rp)

\begin{tabular}{cccccc}
\hline Keterangan & 2013 & 2014 & 2015 & 2016 & $\begin{array}{c}2017 \\
\text { 30 November }\end{array}$ \\
\hline Penerimaan Pajak & $1.077,31$ & $1.146,9$ & 1.240 .4 & 1.285 & $1.125,1$ \\
Penerimaan Negara & $1.436,40$ & $1.550,6$ & $1.504,5$ & $1.555,1$ & $1.395,6$ \\
$\%$ & $75 \%$ & $73,96 \%$ & $82,45 \%$ & $82,63 \%$ & $80,62 \%$ \\
\hline
\end{tabular}

Tetapi jika dilihat dari perbandingan dan realisasi penerimaan pajak (tax antara jumlah penerimaan terhadap gap), jumlah pajak yang diterima Produk Domestik Bruto (tax ratio) Indonesia belum optimal.

dan selisih antara potensi penerimaan

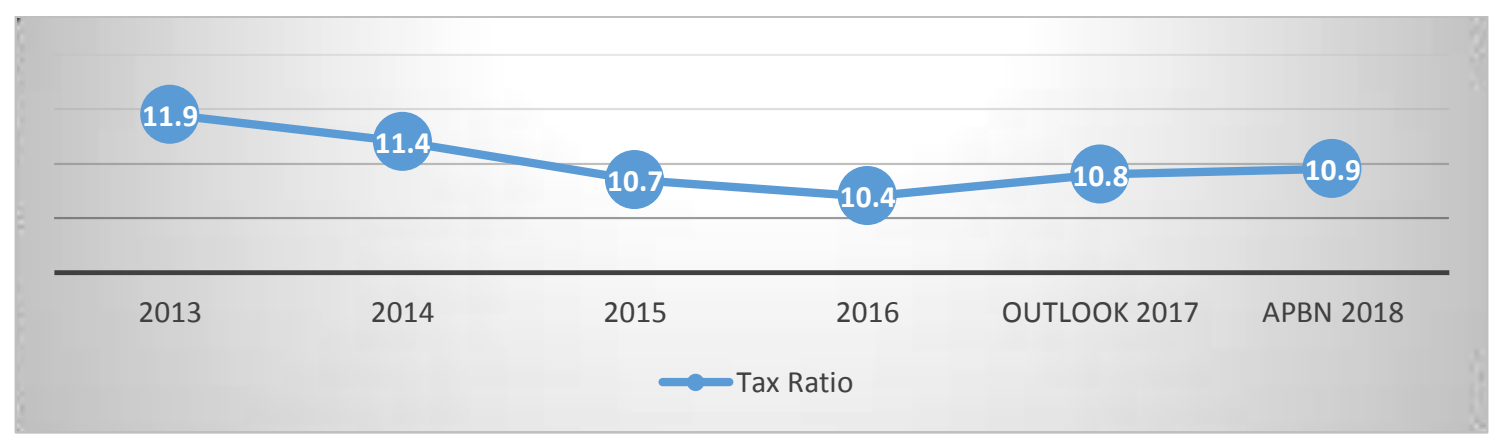

Gambar 1. Tax Ratio Indonesia tahun 2013-2017

Sumber: Diolah dari Kemenkeu (Informasi APBN 2018).

Berdasarkan gambar 1 dapat dilihat ditetapkan oleh pemerintah yaitu bahwa secara umum, rasio pajak sebesar $11,5 \%$ terhadap PDB (tax ratio) Indonesia (nasional.kontan.co.id). Angka tax menurun. Namun pada tahun 2017, ratio yang dihasilkan menunjukkan tax ratio Indonesia meningkat bahwa penerimaan pajak yang menjadi sebesar $10,8 \%$ tetapi masih diperoleh belum optimal berada di bawah target yang 
Analisis Faktor-Faktor yang Mempengaruhi Penggunaan E-Filing Oleh Wajib Pajak

(Studi pada Wajib Pajak Orang Pribadi yang Terdaftar pada KPP Madya dan

Pratama di Kota Tangerang dan Tangerang Selatan)

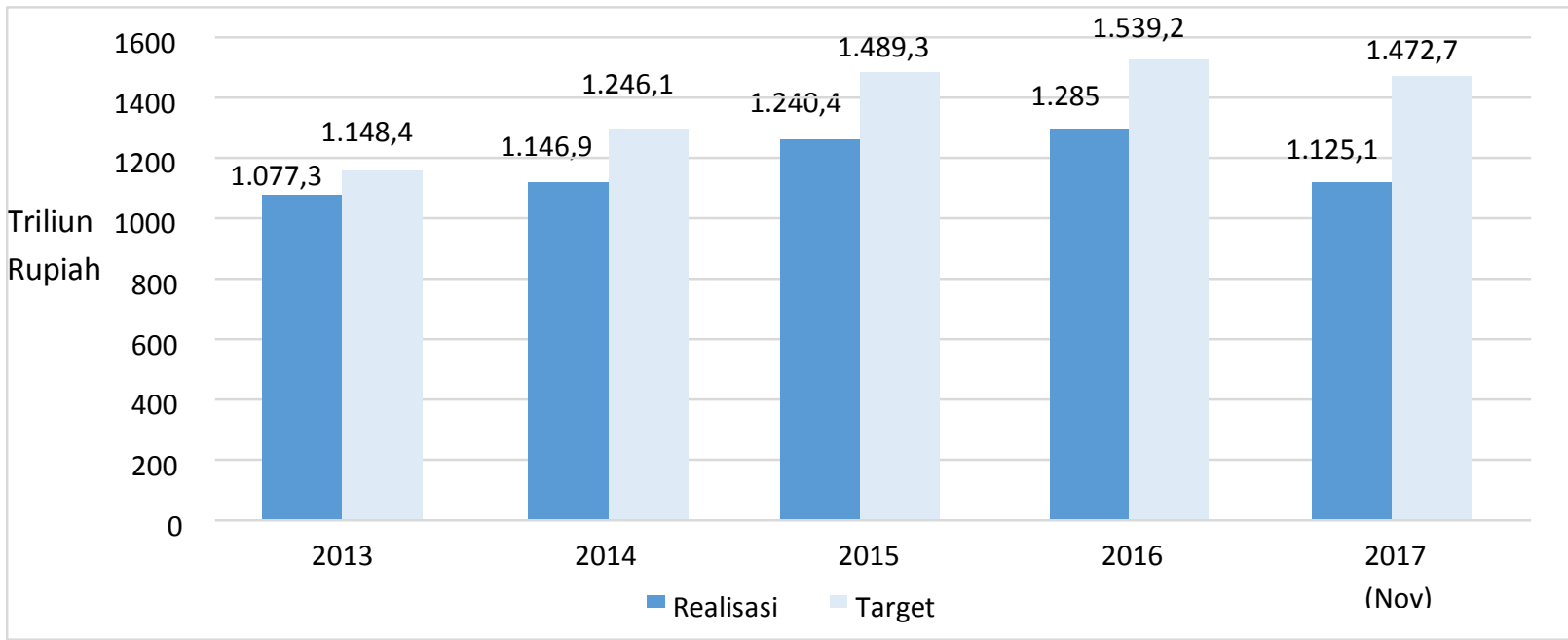

Gambar 2. Tax Gap Indonesia Tahun 2013-2017

Sumber: Diolah dari Kemenkeu.

Berdasarkan gambar 2, realisasi penerimaan pajak selalu meningkat setiap tahun namun tidak melewati target yang ditetapkan. Hal tersebut menunjukkan bahwa penerimaan pajak masih dapat ditingkatkan lagi. Angka tax gap yang signifikan dan tax ratio yang masih rendah menunjukkan usaha memungut pajak (tax effort) Indonesia masih rendah (Dyanrosi, 2015). Pentingnya peranan penerimaan pajak dalam pembiayaan negara menyebabkan Direktorat Jenderal Pajak melakukan upaya untuk meningkatkan penerimaan pajak. Terdapat enam langkah optimalisasi penerimaan pajak yang ditempuh Direktorat Jenderal Pajak untuk meningkatkan penerimaan pajak, salah satu cara yang dilakukan oleh Direktorat
Jenderal Pajak adalah menyempurnakan sistem administrasi perpajakan (Utami dan Osesoga, 2017). Salah satu bentuk modernisasi sistem perpajakan adalah penggunaan teknologi informasi dalam penyampaian surat pemberitahuan pajak (SPT) melalui fasilitas E-Filing (Dharma dan Noviari, 2016).

Menurut website Direktorat Jenderal Pajak, e-Filing adalah suatu cara penyampaian SPT Tahunan secara elektronik yang dilakukan secara online dan realtime melalui internet pada website Direktorat Jenderal Pajak (www.pajak.go.id) atau Penyedia Jasa Aplikasi atau Application Service Provider (ASP). Tujuan utama dari pelaporan $e$-Filing adalah memangkas biaya dan waktu 
Wajib Pajak untuk mempersiapkan, memproses dan melaporkan Surat Pemberitahuan (SPT) ke Kantor Pajak secara benar dan tepat waktu (Herawan dan Waluyo, 2014). Menurut Muzammil dan Budiarto (2016), 7 (tujuh) keuntungan menggunakan $e$-Filing, yaitu

1. Penyampaian SPT dapat dilakukan secara cepat, aman, dan kapan saja

2. Pelaporan SPT menjadi murah

3. Penghitungan jumlah pajak yang harus dibayar oleh Wajib Pajak lebih tepat dan akurat

4. Pengisian formulir disertai dengan panduan langkah demi langkah, membuat Wajib Pajak tidak mengalami kebingungan dalam mengisi SPT

5. Data yang disampaikan Wajib Pajak selalu lengkap karena ada validasi pengisian SPT

6. Ramah lingkungan dengan mengurangi penggunaan kertas; dan

7. Apabila tidak ada permintaan dari Kantor Pelayanan Pajak, dokumen pelengkap tidak perlu dikirim.

Pada tahun 2005, Wajib Pajak hanya bisa mengakses sistem e-Filing melalui perusahaan penyedia jasa Aplikasi atau Application Service Provider. Namun, sejak tahun 2012 Wajib Pajak sudah bisa mengakses sistem e-Filing melalui website resmi Direktorat Jenderal Pajak yaitu www.pajak.go.id (Direktorat Jenderal Pajak, 2018).

Berdasarkan Annual Report DJP 2016, pada tahun 2016 target penyampaian SPT melalui e-Filing sebesar 7.000.000 tetapi ternyata SPT yang disampaikan melalui $e$ Filing melebihi 8 juta SPT yang berarti penyampaian SPT melalui $e$ Filing melebihi target yang ditetapkan. Penggunaan e-Filing digunakan sebagai salah satu strategi untuk meningkatkan kepatuhan Wajib Pajak. Peningkatan kepatuhan Wajib Pajak merupakan salah satu penyebab penerimaan pajak meningkat. 
Analisis Faktor-Faktor yang Mempengaruhi Penggunaan E-Filing Oleh Wajib Pajak (Studi pada Wajib Pajak Orang Pribadi yang Terdaftar pada KPP Madya dan Pratama di Kota Tangerang dan Tangerang Selatan)

Tabel 2. Jumlah Penyampaian SPT Tahunan PPh Orang Pribadi Tahun Pajak 2016 dan 2017

\begin{tabular}{lllll}
\hline & 30 April 2017 & \multicolumn{2}{l}{ 31 Maret 2018 } \\
& Jumlah SPT & $\%$ & Jumlah SPT & $\%$ \\
\hline SPT Manual & 2.052 .492 & $23,36 \%$ & 1.838 .003 & $18,29 \%$ \\
E-Filing & 6.733 .107 & $76,64 \%$ & 8.213 .098 & $81,71 \%$ \\
Total & 8.785 .599 & $100 \%$ & 10.051 .101 & $100 \%$ \\
\hline
\end{tabular}

Sumber: www.kemenkeu.go.id.

Berdasarkan Tabel 2 dapat dilihat bahwa terjadi peningkatan signifikan pada penyampaian SPT dengan menggunakan E-Filing pada tahun 2017 dibandingkan dengan tahun 2016. Hal tersebut menunjukkan bahwa Wajib Pajak sudah beralih dengan menggunakan E-Filing untuk menyampaikan SPT dibandingkan dengan cara manual. Namun, melihat jumlah Wajib Pajak yang masih ada yang menggunakan cara manual untuk melaporkan SPT menunjukkan bahwa pelaporan SPT melalui $E$ Filing masih dapat dioptimalkan lagi. Penggunaan e-Filing adalah suatu cara penyampaian SPT Tahunan secara elektronik yang dilakukan secara online oleh Wajib Pajak dengan menggunakan sistem $e$ Filing. Penggunaan e-Filing dapat diukur dalam beberapa aspek yaitu selalu menggunakan e-Filing setiap melaporkan pajak, berkehendak menggunakan e-Filing di masa depan, serta mempunyai fitur yang membantu Wajib Pajak dalam melaporkan pajak. Jika partisipasi Wajib Pajak dalam penggunaan $E$ Filing masih rendah maka akibatnya adalah return yang diterima Direktorat Jenderal Pajak juga akan menjadi rendah (Dewi dan Ratih dalam Laihad, 2013).

Persepsi kegunaan adalah suatu ukuran dimana penggunaan suatu teknologi dipercaya akan mendatangkan manfaat bagi setiap individu yang menggunakannya (Wahyuni, 2015). Apabila Wajib Pajak merasakan bahwa penggunaan $e$-Filing dapat meningkatkan performa pelaporan pajak, meningkatkan efektivitas pelaporan pajak, menyederhanakan pelaporan pajak, dan meningkatkan produktivitas dalam melaksanakan kewajiban perpajakannya maka Wajib Pajak akan selalu dan berkehendak menggunakan e-Filing di masa depan karena mempunyai fitur yang membantu Wajib Pajak 
untuk melaporkan pajak. Dalam penelitian Devina dan Waluyo (2016) disimpulkan bahwa persepsi kegunaan berpengaruh terhadap penggunaan $e$-Filing .

Persepsi kemudahan penggunaan $e$ Filing adalah suatu ukuran dimana seseorang percaya bahwa sistem $e$ Filing dapat dengan mudah untuk dipahami dan digunakan (Utami dan Osesoga, 2017). Apabila Wajib Pajak merasa bahwa mempelajari penggunaan e-Filing mudah, interaksi dengan e-Filing jelas dan terpahami, menggunakan e-Filing mudah, mudah beradaptasi dengan $e$ Filing, mudah untuk menjadi terampil menggunakan e-Filing, dan secara keseluruhan sistem e-Filing mudah digunakan maka Wajib Pajak akan selalu dan berkehendak menggunakan e-Filing di masa depan karena mempunyai fitur yang membantu Wajib Pajak untuk melaporkan pajak. Hasil penelitian Utami dan Osesoga (2017) menyatakan bahwa persepsi kemudahan berpengaruh positif terhadap penggunaan $e$-Filing.

Keamanan dan kerahasiaan adalah seberapa kuatnya fitur keamanan dan kerahasiaan perangkat teknologi untuk menjaga keamanan dan kerahasiaan data (Wibisono dan Agus, 2014 dalam Dharma dan Noviari, 2016). Apabila Wajib Pajak merasa bahwa pemanfaatan layanan pelaporan pajak dengan menggunakan e-Filing aman, dapat memberikan tingkat jaminan kerahasiaan yang tinggi, percaya bahwa e-Filing dapat menjaga kerahasiaan, tidak khawatir dengan masalah keamanan e-Filing, dan permasalahan tingkat keamanan dan kerahasiaan dalam e-Filing tidak mempengaruhi Wajib Pajak dalam memanfaatkan layanan pelaporan pajak maka Wajib Pajak akan selalu dan berkehendak menggunakan $e$ Filing di masa depan karena mempunyai fitur yang membantu Wajib Pajak untuk melaporkan pajak. Dalam penelitian Herawan dan Waluyo (2014) menyatakan bahwa persepsi keamanan dan kerahasiaan Wajib Pajak berpengaruh signifikan terhadap penggunaan $e$-Filing .

Kesiapan teknologi informasi Wajib Pajak terhadap e-Filing adalah individu dalam hal ini siap menerima perkembangan teknologi yang ada termasuk dengan munculnya sistem 
Analisis Faktor-Faktor yang Mempengaruhi Penggunaan E-Filing Oleh Wajib Pajak (Studi pada Wajib Pajak Orang Pribadi yang Terdaftar pada KPP Madya dan Pratama di Kota Tangerang dan Tangerang Selatan)

e-Filing (Desmayanti, 2012 dalam Devina dan Waluyo, 2016). Apabila tersedia koneksi internet yang baik, sarana serta fasilitas software dan hardware yang baik, dan SDM yang paham akan teknologi maka Wajib Pajak akan selalu dan berkehendak menggunakan e-Filing di masa depan karena mempunyai fitur yang membantu Wajib Pajak untuk melaporkan pajak. Dalam penelitian yang dilakukan Maryani (2016) menyatakan bahwa teknologi informasi berpengaruh secara signifikan terhadap penggunaan $E$ Filing bagi Wajib Pajak.

Kepuasan pengguna adalah suatu keadaan dimana keinginan harapan dan kebutuhan dipenuhi (Utami dan Osesoga, 2017). Apabila sistem $e$ Filing yang berjalan dengan baik dapat membantu dalam melakukan pelaporan secara efisien, melakukan pelaporan SPT secara tepat waktu, menghemat biaya serta energi saat menggunakan e-Filing untuk melaporkan SPT, secara efektif memenuhi kebutuhan saya dalam kaitannya dengan pelaporan pajak, dapat memperoleh informasi yang saya butuhkan saat menggunakan $e$ Filing, dapat memberi informasi sesuai format, memberikan kepuasan terhadap Wajib Pajak dalam hal pelayanan sistem e-Filing serta informasi yang dihasilkan sistem $e$ Filing, memberikan pengalaman yang menyenangkan saat menggunakan sistem e-Filing, dan rasa bangga telah menggunakan sistem e-Filing saat melaporkan SPT maka Wajib Pajak akan selalu dan berkehendak menggunakan e-Filing di masa depan karena mempunyai fitur yang membantu Wajib Pajak untuk melaporkan pajak. Dalam penelitian yang dilakukan Maryani (2016) menyatakan bahwa kepuasan pengguna berpengaruh secara signifikan terhadap penggunaan $e$ filing bagi Wajib Pajak.

\subsection{Batasan Masalah}

1. Analisis penggunaan E-Filing sebagai variabel dependen dan persepsi kegunaan, persepsi kemudahan, keamanan dan kerahasiaan, kesiapan teknologi informasi, dan kepuasan sebagai variabel independen.

2. Objek yang diteliti adalah Wajib Pajak Orang Pribadi yang menggunakan E-Filing 
yang terdaftar pada KPP

Madya dan Pratama di Kota Tangerang dan Tangerang Selatan.

3. Jangka waktu penelitian yang dilakukan adalah selama tahun 2018.

\subsection{Rumusan Masalah}

Berdasarkan latar belakang penelitian, maka rumusan masalah penelitian ini adalah sebagai berikut:

1. Apakah persepsi kegunaan (perceived usefulness) berpengaruh terhadap penggunaan E-Filing (E-Filing usage)?

2. Apakah persepsi kemudahan (perceived easy of use) berpengaruh terhadap penggunaan E-Filing (E-Filing usage)?

3. Apakah keamanan dan kerahasiaan (security and privacy) berpengaruh terhadap penggunaan E-Filing (E-Filing usage)?

4. Apakah kesiapan teknologi informasi (readiness technology taxpayer information) berpengaruh terhadap penggunaan E-Filing (E-Filing usage)?

5. Apakah kepuasan pengguna (user satisfaction) berpengaruh terhadap penggunaan $E$-filing ( $E$ Filing usage)?

\subsection{Tujuan Penelitian}

Berdasarkan latar belakang penelitian dan rumusan masalah yang telah disajikan maka tujuan dari penelitian ini adalah:

1. Untuk memperoleh bukti empiris pengaruh persepsi kegunaan (perceived usefulness) terhadap penggunaan E-Filing (E-Filing usage)?

2. Untuk memperoleh bukti empiris pengaruh persepsi kemudahan (perceived easy of use) terhadap penggunaan E-Filing (E-Filing usage)?

3. Untuk memperoleh bukti empiris pengaruh keamanan dan kerahasiaan (security and privacy) terhadap penggunaan $E$ Filing (E-Filing usage) ?

4. Untuk memperoleh bukti empiris pengaruh kesiapan teknologi informasi (readiness technology taxpayer information) terhadap 
Analisis Faktor-Faktor yang Mempengaruhi Penggunaan E-Filing Oleh Wajib Pajak (Studi pada Wajib Pajak Orang Pribadi yang Terdaftar pada KPP Madya dan Pratama di Kota Tangerang dan Tangerang Selatan)

penggunaan E-Filing (E-Filing usage)?

5. Untuk memperoleh bukti empiris pengaruh kepuasan pengguna (user satisfaction) terhadap penggunaan E-Filing (E-Filing usage)?

\section{TELAAH LITERATUR}

\subsection{Pajak}

\subsubsection{Pengertian Pajak}

Definisi pajak dalam UndangUndang Republik Indonesia Nomor 28 Tahun 2007 dalam pasal 1 angka 1 berbunyi, pajak adalah kontribusi wajib kepada negara yang terutang oleh orang pribadi atau badan yang bersifat memaksa berdasarkan Undang-Undang, dengan tidak mendapatkan imbalan secara langsung dan digunakan untuk keperluan negara bagi sebesarbesarnya kemakmuran rakyat.

\subsubsection{Fungsi Pajak}

Menurut Resmi (2017), terdapat dua fungsi pajak yaitu fungsi budgetair (sumber keuangan negara) dan fungsi regularend (pengatur).

1. Fungsi Budgetair (Sumber Keuangan Negara)
Pajak mempunyai fungsi budgetair, artinya pajak merupakan salah satu sumber penerimaan pemerintah untuk membiayai pengeluaran baik rutin maupun pembangunan.

2. Fungsi Regularend (Pengatur)

Pajak mempunyai fungsi pengatur, artinya pajak sebagai alat untuk mengatur atau melaksanakan kebijakan pemerintah dalam bidang sosial dan ekonomi, serta mencapai tujuan-tujuan tertentu diluar bidang keuangan.

\subsubsection{Jenis Pajak}

Menurut Waluyo (2017), pajak dapat dikelompokkan ke dalam tiga kelompok, adalah sebagai berikut.

1. Menurut golongan atau pembebanan, dibagi menjadi berikut ini.

a. Pajak langsung adalah pajak yang pembebannya tidak dapat dilimpahkan pihak lain, tetapi harus menjadi beban langsung Wajib Pajak yang bersangkutan.

b. Pajak tidak langsung adalah pajak yang pembebanannya dapat dilimpahkan ke pihak lain. 
2. Menurut sifat

a. Pajak subjektif adalah pajak yang berpangkal atau berdasarkan pada subjeknya yang selanjutnya dicari syarat objektifnya, dalam arti memperhatikan keadaan dari Wajib Pajak.

b. Pajak objektif adalah pajak yang berpangkal atau berdasarkan pada objeknya, tanpa memerhatikan keadaan diri Wajib Pajak.

3. Menurut pemungut dan pengelolanya, adalah sebagai berikut.

a. Pajak pusat adalah pajak yang dipungut oleh pemerintah pusat dan digunakan untuk membiayai rumah tangga negara.

b. Pajak daerah adalah pajak yang dipungut oleh pemerintah daerah dan digunakan untuk membiayai rumah tangga daerah.

\subsubsection{Tata Cara Pemungutan pajak}

Menurut Waluyo (2017), cara pemungutan pajak dilakukan berdasarkan 3 (tiga) stelsel, adalah sebagai berikut.

a. Stelsel nyata (riil stelsel)

Pemungutan pajak didasarkan pada objek (penghasilan) yang nyata, sehingga pemungutannya baru dapat dilakukan pada akhir tahun pajak, yakni setelah penghasilan yang sesungguhnya telah dapat diketahui.

b. Stelsel anggapan (fictive stelsel)

Pengenaan pajak didasarkan pada suatu anggapan yang diatur oleh undang-undang sebagai contoh; penghasilan suatu tahun dianggap sama dengan tahun sebelumnya sehingga pada awal tahun pajak telah dapat ditetapkan besarnya pajak yang terutang untuk tahun pajak berjalan.

c. Stelsel campuran

Stelsel ini merupakan kombinasi antara stelsel nyata dan stelsel anggapan. Pada awal tahun, besarnya pajak dihitung berdasarkan suatu anggapan, kemudian pada akhir tahun besarnya pajak disesuaikan dengan keadaan sebenarnya.

Menurut Resmi (2017), terdapat tiga asas pemungutan pajak, yaitu:

1. Asas Domisili (Asas Tempat Tinggal)

Asas ini menyatakan bahwa negara berhak mengenakan pajak atas 
Analisis Faktor-Faktor yang Mempengaruhi Penggunaan E-Filing Oleh Wajib Pajak (Studi pada Wajib Pajak Orang Pribadi yang Terdaftar pada KPP Madya dan Pratama di Kota Tangerang dan Tangerang Selatan)

seluruh penghasilan Wajib Pajak yang bertempat tinggal di wilayahnya baik penghasilan yang berasal dari dalam maupun luar negeri.

2. Asas Sumber

Asas ini menyatakan bahwa negara berhak mengenakan pajak atas penghasilan yang bersumber di wilayahnya tanpa memerhatikan tempat tinggal Wajib Pajak.

3. Asas Kebangsaan

Asas ini menyatakan bahwa pengenaan pajak dihubungkan dengan kebangsaan suatu negara.

(2017) menyatakan, sistem pemungutan pajak dapat dibagi menjadi berikut ini.

\section{Sistem Official Assessment}

Sistem ini merupakan sistem pemungutan pajak yang memberi wewenang kepada pemerintah (fiskus) untuk menentukan besarnya pajak yang terutang.

\section{Sistem Self Assesment}

Sistem ini merupakan sistem pemungutan pajak yang memberi wewenang, kepercayaan, tanggung jawab kepada Wajib Pajak untuk menghitung, memperhitungkan, membayar, dan melaporkan sendiri besarnya pajak yang harus dibayar

\section{Sistem Withholding}

Sistem ini merupakan sistem pemungutan pajak yang memberi wewenang kepada pihak ketiga untuk memotong atau memungut besarnya pajak yang terutang oleh Wajib Pajak.

Berdasarkan UU Republik Indonesia Tentang Ketentuan Umum dan Tata Cara Perpajakan Nomor 28 tahun 2007, sistem berlaku di Indonesia adalah Self Assessment System.

\subsubsection{Wajib Pajak}

Berdasarkan

Undang-Undang Republik Indonesia Tentang Ketentuan Umum dan Tata Cara Perpajakan Nomor 28 tahun 2007 disebutkan bahwa: "Wajib Pajak adalah orang pribadi atau badan, meliputi pembayar pajak, pemotong pajak, dan pemungut pajak yang mempunyai hak dan kewajiban perpajakan sesuai dengan ketentuan peraturan perundang-undangan perpajakan." Subjek pajak diartikan sebagai orang atau badan atau pihak yang dituju oleh undang-undang untuk dikenai pajak. Subjek pajak dibedakan menjadi subjek pajak dalam negeri dan subjek pajak luar negeri. 


\subsection{Surat Pemberitahuan (SPT)}

Berdasarkan Pasal 1 ayat 1 Peraturan Menteri Keuangan Republik Indonesia Nomor 9/PMK.03/2018, menjelaskan bahwa pengertian Surat Pemberitahuan yang selanjutnya disebut SPT adalah surat yang oleh Wajib Pajak digunakan untuk melaporkan perhitungan dan/atau pembayaran pajak, objek pajak dan/atau bukan objek pajak dan/atau harta dan kewajiban, sesuai dengan ketentuan peraturan perundangundangan perpajakan.

Menurut Waluyo (2017), fungsi SPT bagi Wajib Pajak yaitu:

1. Bagi Pengusaha

Bagi pengusaha bahwa SPT Pajak Penghasilan yaitu berfungsi sebagai sarana melaporkan dan mempertanggungjawabkan penghitungan jumlah pajak yang sebenarnya terutang.

\section{Bagi Pengusaha Kena Pajak}

Bagi Pengusaha Kena Pajak, fungsi SPT adalah sebagai sarana untuk melaporkan dan mempertanggungjawabkan penghitungan jumlah Pajak Pertambahan Nilai dan Pajak
Penjualan atas Barang Mewah yang sebenarnya terutang.

3. Bagi Pemotong atau Pemungut Pajak

Bagi pemotong atau pemungut pajak, fungsi Surat Pemberitahuan adalah sebagai sarana melaporkan dan mempertanggungjawabkan pajak yang dipotong atau dipungut dan disetorkannya.

Berdasarkan Peraturan Menteri Keuangan Republik Indonesia Nomor 9/PMK.03/2018 tentang Perubahan Atas Peraturan Menteri Keuangan Nomor 243/PMK.03/2014 tentang Surat Pemberitahuan, SPT meliputi: SPT Masa dan SPT Tahunan PPh. Berdasarkan Peraturan Menteri Keuangan Republik Indonesia Nomor 243/PMK.03/2014 menjelaskan SPT berbentuk: formulir kertas (hardcopy); atau dokumen elektronik.

Berdasarkan Peraturan Direktur Jenderal Pajak Nomor PER01/PJ/2016 tentang Tata Cara Penerimaan dan Pengolahan Surat Pemberitahuan dalam Pasal 1 ayat (2) dijelaskan bahwa Surat Pemberitahuan Tahunan yang selanjutnya disebut SPT Tahunan adalah Surat Pemberitahuan untuk 
suatu Tahun Pajak atau Bagian Tahun Pajak, yang meliputi SPT Tahunan Pajak Penghasilan Wajib Pajak Orang Pribadi (SPT 1770, SPT 1770 S, SPT 1770 SS) dan SPT Tahunan Pajak Penghasilan Wajib Pajak Badan (SPT 1771 dan SPT 1771/\$), termasuk SPT Tahunan Pembetulan.

Menurut Waluyo (2017), SPT yang telah diisi selanjutnya Wajib Pajak menyampaikan SPT tersebut ke Kantor Pelayanan Pajak atau tempat lain yang ditetapkan oleh Direktur Jenderal Pajak dapat dilakukan: secara langsung; melalui pos dengan bukti pengiriman surat; atau cara lain.

Berdasarkan Peraturan Menteri Keuangan Republik Indonesia Nomor 243/PMK.03/2014 tentang Surat Pemberitahuan menjelaskan batas waktu penyampaian SPT untuk: Wajib Pajak orang pribadi wajib menyampaikan SPT Tahunan Pajak Penghasilan Wajib Pajak orang pribadi paling lama 3 (tiga) bulan setelah akhir Tahun Pajak dan Wajib Pajak badan wajib menyampaikan SPT Tahunan Pajak Penghasilan Wajib Pajak badan paling lama 4 (empat) bulan setelah akhir Tahun
Pajak. Perpanjangan jangka waktu penyampaian SPT Tahunan untuk: Wajib Pajak dapat memperpanjang jangka waktu penyampaian SPT Tahunan paling lama 2 (dua) bulan sejak batas waktu penyampaian SPT Tahunan dengan cara menyampaikan pemberitahuan perpanjangan SPT Tahunan dan pemberitahuan perpanjangan SPT Tahunan disampaikan dalam bentuk formulir kertas (hardcopy) atau dalam bentuk dokumen elektronik.

\subsection{E-Filing}

Menurut website Direktorat Jenderal Pajak, e-Filing adalah suatu cara penyampaian SPT Tahunan secara elektronik yang dilakukan secara online dan realtime melalui internet pada website Direktorat Jenderal Pajak (www.pajak.go.id) atau Penyedia Jasa Aplikasi atau Application Service Provider (ASP). Berdasarkan Peraturan Direktur Jenderal Pajak Nomor PER01/PJ/2017 tentang Penyampaian Surat Pemberitahuan Elektronik untuk dapat menyampaikan SPT elektronik dengan menggunakan fasilitas E-Filing Wajib Pajak harus memiliki: e-FIN yang diterbitkan 
oleh Direktorat Jenderal Pajak, memiliki aplikasi SPT, dan Sertifikat Digital (Digital Certificate).

\subsection{Penggunaan Electronic Filing (E-Filing)}

Penggunaan e-Filing merupakan suatu proses di mana Wajib Pajak menggunakan sistem e-Filing untuk melaporkan SPT secara online. EFiling diciptakan dengan tujuan memberi keuntungan dan kemudahan bagi pihak Direktorat Jenderal Pajak dan Wajib Pajak dalam pelaporan SPT. Jika para Wajib Pajak tidak bersedia menerima $e$-Filing, maka $e$ Filing tidak dapat memberikan manfaat maksimal kepada Direktorat Jenderal Pajak (Herawan dan Waluyo, 2014). Kriteria yang digunakan untuk menilai penggunaan e-Filing oleh Wajib Pajak yaitu ketika (1) Wajib Pajak selalu menggunakan e-Filing setiap kali melaporkan pajaknya, (2) Wajib Pajak berkehendak untuk melanjutkan menggunakan e-Filing di masa depan (3) Wajib Pajak menggunakan e-Filing karena mempunyai fitur yang membantu pekerjaannya.
Ada beberapa teori yang berusaha menjelaskan mengenai minat individu untuk menggunakan suatu teknologi. Theory of Planned Behavior (TPB) menggunakan tiga faktor utama yaitu keyakinan perilaku (behavioral), keyakinan normatif (normative beliefs), dan keyakinan bahwa perilaku dapat dilaksanakan (control beliefs) untuk mempelajari perilaku manusia (Ajzen, 1991 dalam Dharma dan Noviari, 2016). Minat individu akan menggunakan suatu sistem (e-filing) ditimbulkan oleh faktor-faktor tersebut. Task Technology Fit (TTF) adalah tingkat dimana teknologi membantu individu dalam pelaksanaan tugas-tugasnya atau tugas jabatan. Model ini mengindikasikan bahwa kinerja akan meningkat ketika sebuah teknologi menyediakan fitur dan dukungan yang tepat dikaitkan dengan tugas (Nurjannah, 2017). Technology Acceptance Model (TAM) adalah suatu model untuk memprediksi dan menjelaskan bagaimana pengguna teknologi menerima dan menggunakan teknologi tersebut dalam pekerjaan individual pengguna (Davis, 2000). Tujuan dari 
Analisis Faktor-Faktor yang Mempengaruhi Penggunaan E-Filing Oleh Wajib Pajak (Studi pada Wajib Pajak Orang Pribadi yang Terdaftar pada KPP Madya dan Pratama di Kota Tangerang dan Tangerang Selatan)

Technology Acceptance Model

(TAM) ini adalah untuk menjelaskan sikap individu terhadap penggunaan suatu teknologi. Penerimaan pengguna teknologi informasi merupakan faktor penting dalam penggunaan dan pemanfaatan sistem informasi yang dikembangkan (Nurjannah, 2017).

\subsection{Persepsi Kegunaan}

Menurut Kamus Besar Bahasa Indonesia (KBBI) Daring (2018), persepsi adalah tanggapan (penerimaan) langsung dari sesuatu; serapan atau proses seseorang mengetahui beberapa hal melalui pancaindranya. Menurut Herawan dan Waluyo (2014), persepsi kegunaan (perceived usefulness) adalah tingkatan sejauh mana seseorang yakin bahwa dengan menggunakan sebuah sistem akan meningkatkan kinerjanya. Indikator yang digunakan untuk menilai kegunaan penggunaan $e$-Filing yaitu meningkatkan performa pelaporan pajak, (2) meningkatkan efektivitas pelaporan pajak, (3) menyederhanakan pelaporan pajak, dan (4) meningkatkan produktivitas dalam melaksanakan kewajiban perpajakannya.

Berdasarkan hasil penelitian yang telah dilakukan Laihad (2013) menunjukkan bahwa persepsi kegunaan (perceived usefulness) secara signifikan berpengaruh terhadap penggunaan E-Filing. Dalam penelitian Devina dan Waluyo (2016) disimpulkan bahwa persepsi kegunaan berpengaruh terhadap penggunaan $e$-Filing .

$\mathrm{Ha}_{1}$ : Persepsi Kegunaan berpengaruh terhadap penggunaan E-Filing.

\subsection{Persepsi Kemudahan}

Menurut Utami dan Osesoga (2017), persepsi kemudahan penggunaan $e$ Filing adalah suatu ukuran dimana seseorang percaya bahwa sistem $e$ Filing dapat dengan mudah untuk dipahami dan digunakan. Indikator yang digunakan untuk menilai kemudahan penggunaan e-Filing yaitu (1) mempelajari penggunaan $e$ Filing mudah, (2) interaksi dengan $e$ Filing jelas dan terpahami, menggunakan e-Filing mudah, (4) mudah beradaptasi dengan e-Filing, (5) mudah untuk menjadi terampil menggunakan e-Filing, dan (6) 
secara keseluruhan sistem e-Filing mudah digunakan.

Berdasarkan hasil penelitian yang telah dilakukan Laihad (2013) menunjukkan bahwa persepsi kemudahan berpengaruh positif dan signifikan terhadap penggunaan $E$ Filing.

$\mathrm{Ha}_{2}$ : Persepsi Kemudahan berpengaruh terhadap penggunaan $E$ Filing.

\subsection{Keamanan dan Kerahasiaan}

Menurut Utami dan Osesoga (2017), keamanan dan kerahasiaan e-Filing berarti bahwa data dan informasi yang dimiliki Wajib Pajak ketika menggunakan e-Filing aman dan terjamin kerahasiaannya. Indikator yang digunakan untuk menilai keamanan dan kerahasiaan terhadap penggunaan e-Filing yaitu (1) pemanfaatan layanan pelaporan pajak dengan menggunakan e-Filing aman, (2) dapat memberikan tingkat jaminan kerahasiaan yang tinggi, (3) percaya bahwa e-Filing dapat menjaga kerahasiaan, (4) tidak khawatir dengan masalah keamanan e-Filing, dan (5) permasalahan tingkat keamanan dan kerahasiaan dalam e-Filing tidak mempengaruhi
Wajib Pajak dalam memanfaatkan layanan pelaporan pajak.

Hasil penelitian Dharma dan Noviari (2016) menunjukkan bahwa keamanan dan kerahasiaan berpengaruh positif terhadap intesitas perilaku penggunaan E-Filing oleh Wajib Pajak Orang Pribadi di KPP Pratama Denpasar Timur.

$\mathrm{Ha}_{3}$ : Keamanan dan Kerahasiaan berpengaruh terhadap penggunaan $E$ Filing.

\subsection{Kesiapan Teknologi Informasi}

Kesiapan teknologi informasi Wajib Pajak terhadap e-Filing adalah individu dalam hal ini siap menerima perkembangan teknologi yang ada termasuk dengan munculnya sistem e-Filing (Desmayanti, 2012 dalam Devina dan Waluyo, 2016). Indikator yang digunakan untuk menilai kesiapan teknologi informasi terhadap penggunaan e-Filing yaitu (1) tersedia koneksi internet yang baik, (2) sarana serta fasilitas software dan hardware yang baik, dan (3) SDM yang paham akan teknologi.

Berdasarkan hasil pengujian Maryani (2016) menyatakan bahwa kesiapan teknologi informasi berpengaruh 
Analisis Faktor-Faktor yang Mempengaruhi Penggunaan E-Filing Oleh Wajib Pajak (Studi pada Wajib Pajak Orang Pribadi yang Terdaftar pada KPP Madya dan Pratama di Kota Tangerang dan Tangerang Selatan)

secara signifikan terhadap saya dalam kaitannya dengan penggunaan e-Filing bagi Wajib pelaporan pajak, (5) dapat Pajak.

$\mathrm{Ha}_{4}$ : Kesiapan Teknologi Informasi berpengaruh terhadap penggunaan $E$ Filing.

\subsection{Kepuasan Pengguna}

Menurut Utami dan Osesoga (2017), kepuasan pengguna adalah suatu keadaan dimana keinginan harapan dan kebutuhan dipenuhi. Indikator yang digunakan untuk menilai kepuasan pengguna terhadap penggunaan $e$-Filing yaitu (1) sistem e-Filing dapat membantu dalam melakukan pelaporan secara efisien, (2) sistem e-Filing dapat membantu melakukan pelaporan SPT secara tepat waktu, (3) dapat menghemat biaya serta energi saat menggunakan $e$-Filing untuk melaporkan SPT, (4) secara efektif memenuhi kebutuhan memperoleh informasi yang saya butuhkan saat menggunakan $e$ Filing, (6) dapat memberi informasi sesuai format yang dibutuhkan, (7) merasa puas dengan pelayanan sistem e-Filing, (8) merasa puas dengan informasi yang dihasilkan sistem e-Filing, (9) memiliki pengalaman yang menyenangkan saat menggunakan sistem e-Filing, dan (10) merasa bangga telah menggunakan sistem e-Filing saat melaporkan SPT.

Berdasarkan hasil pengujian Maryani (2016) menyatakan bahwa kepuasan pengguna berpengaruh secara signifikan terhadap penggunaan $e$ filing bagi Wajib Pajak.

Has: Kepuasan Pengguna berpengaruh terhadap penggunaan $E$ Filing. 


\subsection{Model Penelitian}

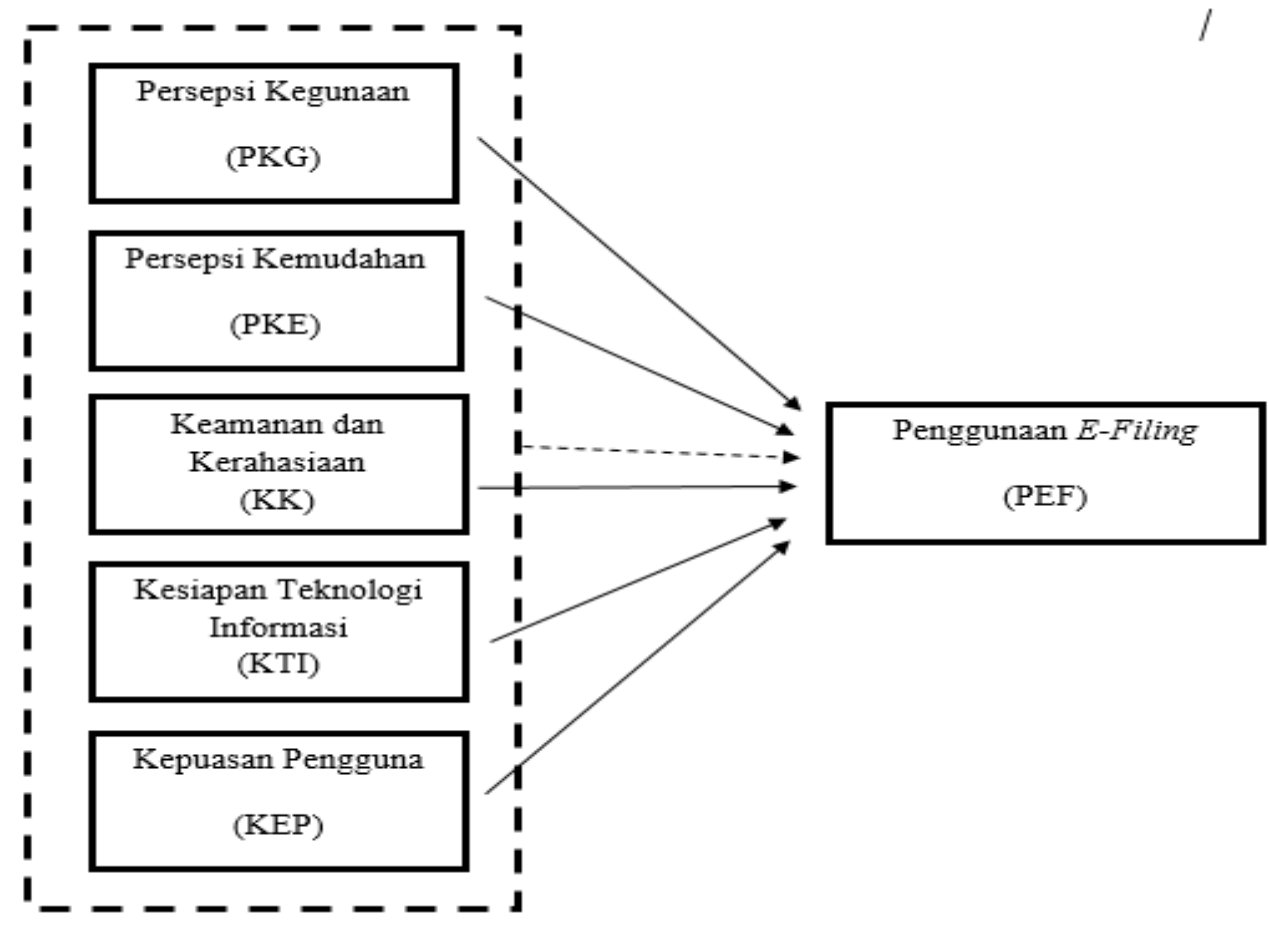

Gambar 3. Model Penelitian

\section{METODOLOGI PENELITIAN}

\subsection{Gambaran Umum Objek} Penelitian

Objek penelitian yang digunakan dalam penelitian ini ialah Wajib Pajak Orang Pribadi yang menggunakan serta memanfaatkan layanan E-Filing dan terdaftar pada Kantor Pelayanan Pajak Madya dan Pratama yang berlokasi di Kota Tangerang dan Tangerang Selatan.

\subsection{Metode Penelitian}

Metode yang digunakan dalam penelitian ini adalah causal study. Causal study ialah penelitian yang dilakukan untuk menguji apakah satu variabel menyebabkan variabel lainnya untuk berubah (Sekaran dan Bougie, 2016).

\subsection{Variabel Penelitian}

Variabel-variabel yang diteliti dalam penelitian ini ialah variabel dependen (variabel yang dipengaruhi) dan variabel independen (variabel yang mempengaruhi). Variabel dependen ialah variabel yang menjadi kepentingan utama bagi peneliti. (Sekaran dan Bougie, 2016). Variabel independen adalah variabel yang mempengaruhi variabel 
Analisis Faktor-Faktor yang Mempengaruhi Penggunaan E-Filing Oleh Wajib Pajak (Studi pada Wajib Pajak Orang Pribadi yang Terdaftar pada KPP Madya dan Pratama di Kota Tangerang dan Tangerang Selatan)

dependen dengan cara positif atau negatif (Sekaran dan Bougie, 2016).

\subsubsection{Variabel Dependen}

Variabel dependen dalam penelitian ini adalah penggunaan E-Filing. Penggunaan E-Filing yaitu suatu proses dimana Wajib Pajak Orang Pribadi menggunakan sistem $E$ Filing secara berkelanjutan untuk melaporkan SPT karena memiliki fitur yang membantu pekerjaan Wajib Pajak.

\subsubsection{Variabel Independen}

Variabel independen dalam penelitian ini ada lima (5), yaitu persepsi kegunaan $\left(\mathrm{X}_{1}\right)$, persepsi kemudahan $\left(\mathrm{X}_{2}\right)$, keamanan dan kerahasiaan $\left(\mathrm{X}_{3}\right)$, kesiapan teknologi informasi $\left(\mathrm{X}_{4}\right)$, dan kepuasan pengguna $\left(\mathrm{X}_{5}\right)$.

1. Persepsi kegunaan $\left(\mathrm{X}_{1}\right)$ adalah suatu interpretasi bahwa pemakaian sistem memberikan manfaat atau kegunaan bagi pengguna atau Wajib Pajak Orang Pribadi. Persepsi kegunaan diukur dengan kuesioner dalam penelitian Dharma dan Noviari (2016) yang terdiri dari 4 butir pertanyaan.
2. Persepsi kemudahan $\left(\mathrm{X}_{2}\right)$ adalah suatu interpretasi bahwa sistem dapat dengan mudah dipelajari dan digunakan oleh individu atau Wajib Pajak Orang Pribadi. Persepsi kemudahan diukur dengan kuesioner dalam penelitian Dharma dan Noviari (2016) yang terdiri dari 6 butir pertanyaan.

3. Keamanan dan Kerahasiaan $\left(X_{3}\right)$ adalah seberapa kuatnya fitur keamanan dan kerahasiaan perangkat teknologi untuk menjaga keamanan dan kerahasiaan data. Keamanan dan kerahasiaan diukur dengan kuesioner dalam penelitian Dharma dan Noviari (2016) yang terdiri dari 5 butir pertanyaan.

4. Kesiapan teknologi informasi $\left(\mathrm{X}_{4}\right)$ adalah individu atau Wajib Pajak Orang Pribadi siap menerima perkembangan teknologi yang ada termasuk dengan munculnya sistem $e$ filing. Kesiapan teknologi informasi diukur dengan kuesioner dalam penelitian Maryani (2016) yang terdiri dari 3 butir pertanyaan. 
5. Kepuasan pengguna $\left(\mathrm{X}_{4}\right)$ adalah suatu individu atau Wajib Pajak Orang Pribadi yang merasa harapan, keinginan dan kepentingan pribadi terjawab sehingga memunculkan rasa puas dalam melaporkan SPT melalui sistem e-Filing. Kepuasan pengguna diukur dengan kuesioner dalam penelitian Maryani (2016) yang terdiri dari 10 butir pertanyaan.

\subsection{Teknik Pengumpulan Data}

Pengumpulan data di dalam penelitian ini ialah menggunakan data primer. Data primer adalah data yang dikumpulkan melalui "tangan pertama" untuk analisis selanjutnya agar menemukan solusi. (Sekaran dan Bougie, 2016). Pengumpulan data dalam penelitian ini menggunakan instrumen kuesioner. Kuesioner tersebut disebarkan untuk selanjutnya diisi oleh para responden Wajib Pajak Orang Pribadi yang terdaftar pada Kantor Pelayanan Pajak Madya dan Pratama Kota Tangerang dan Tangerang Selatan.

\subsection{Teknik Pengambilan Sampel}

Populasi dalam penelitian ini ialah para Wajib Pajak Orang Pribadi yang terdaftar di KPP Madya dan Pratama yang berada di Kota Tangerang dan Tangerang Selatan. Sampel dalam penelitian ini ialah Wajib Pajak Orang Pribadi yang menggunakan dan memanfaatkan E-Filing serta terdaftar di KPP Madya dan Pratama Kota Tangerang dan Tangerang Selatan. Teknik pengambilan sampel yang digunakan adalah dengan menggunakan non-probability sampling. Pengambilan sampelnya menggunakan teknik convenience sampling.

\subsection{Teknik Analisis Data}

Semua uji dalam penelitian ini menggunakan bantuan software SPSS (Statistic Product and Service Solution) versi ke-25.

\subsubsection{Statistik Deskriptif}

Statistik deskriptif berhubungan erat dengan analisa secara deskriptif. Menurut Ghozali (2018) menjelaskan bahwa statistik deskriptif memberikan gambaran atau deskripsi suatu data yang dilihat dari nilai ratarata (mean), standar deviasi, maksimum, minimum, dan range. 


\subsubsection{Uji Kualitas Data}

\section{Uji Validitas}

Menurut Sekaran dan Bougie (2016), validitas adalah suatu tes mengenai seberapa baik instrumen digunakan untuk mengukur sebuah konsep yang dimaksudkan. Uji validitas digunakan untuk mengukur sah atau valid tidaknya suatu kuesioner. Validitas dihitung setiap butirnya dengan rumus korelasi Pearson. Signifikansi korelasi Pearson yang dipakai dalam penelitian ini adalah 0,05 (Ghozali, 2018).

\section{Uji Reabilitas}

Ghozali (2018) menyatakan bahwa reliabilitas adalah alat untuk mengukur suatu kuesioner yang merupakan indikator dari variabel atau konstruk. Suatu kuesioner dikatakan reliabel atau handal jika jawaban seseorang terhadap pertanyaan adalah konsisten atau stabil dari waktu ke waktu. Pengukuran reliabilitas dapat dilakukan dengan uji statistik Cronbach Alpha. Suatu konstruk atau variabel dikatakan reliabel jika memberikan nilai Cronbach Alpha >
0,70 (Nunnally, 1994 dalam Ghozali, 2018).

\section{Uji Normalitas}

Uji normalitas bertujuan untuk menguji apakah dalam model regresi, variabel pengganggu atau residual memiliki distribusi normal. Di dalam penelitian ini menggunakan normal probability plot yang membandingkan distribusi kumulatif dari distribusi normal.

\subsubsection{Uji Asumsi Klasik}

\section{a. Uji Multikolonieritas}

Uji multikolonieritas bertujuan untuk menguji apakah model regresi ditemukan adanya korelasi antar variabel bebas (independen). Dalam penelitian ini, multikolonieritas dapat dilihat dari nilai tolerance dan lawannya variance inflation factor $(V I F)$. Nilai cutoff yang umum dipakai untuk menunjukkan adanya multikolonieritas adalah nilai Tolerance $\leq 0,10$ atau sama dengan nilai $V I F \geq 10$ (Ghozali, 2018).

\section{b. Uji Heteroskedastisitas}

Uji Heteroskedastisitas bertujuan menguji apakah dalam model regresi terjadi ketidaksamaan variance dari 
residual satu pengamatan ke pengamatan yang lain. (Ghozali, 2018). Menurut (Ghozali, 2018), dasar analisis: jika ada pola tertentu, seperti titik-titik yang ada membentuk pola tertentu yang teratur (bergelombang, melebar kemudian menyempit), maka mengindikasikan telah terjadi heteroskedastisitas; dan Jika tidak ada pola yang jelas, serta titik-titik yang menyebar di atas dan di bawah angka 0 pada sumbu $\mathrm{Y}$, maka tidak terjadi heteroskedastisitas.

\subsubsection{Uji Hipotesis}

Metode analisis pada penelitian ini menggunakan analisis regresi linear berganda. Metode penelitian ini digunakan karena terdapat lebih dari satu variabel independen. Analisis regresi linear berganda digunakan untuk menunjukkan arah hubungan antara variabel independen yaitu persepsi kegunaan, persepsi kemudahan, keamanan dan kerahasiaan, kesiapan teknologi informasi, dan kepuasan pengguna terhadap variabel dependen yaitu penggunaan e-filing. Persamaan regresi dapat dituliskan sebagai berikut:

$$
P E F=\alpha+\beta_{1} P K G+\beta_{2} P K E+\beta_{3} K K+\beta_{4} K T I+\beta_{5} K E P+e
$$

\section{Keterangan:}

$\begin{array}{ll}\text { PEF } & =\text { Pengunaan E-Filing } \\ \alpha & =\text { Konstanta } \\ \beta_{1,2,3,4,5} & =\text { Koefisien Regresi } \\ \mathrm{PKG} & =\text { Persepsi Kegunaan } \\ \mathrm{PKE} & =\text { Persepsi Kemudahan } \\ \mathrm{KK} & =\text { Keamanan dan Kerahasiaan } \\ \mathrm{KTI} & =\text { Kesiapan Teknologi Informasi } \\ \mathrm{KEP} & =\text { Kepuasan Pengguna } \\ e & =\text { Error }\end{array}$


Analisis Faktor-Faktor yang Mempengaruhi Penggunaan E-Filing Oleh Wajib Pajak (Studi pada Wajib Pajak Orang Pribadi yang Terdaftar pada KPP Madya dan Pratama di Kota Tangerang dan Tangerang Selatan)

\section{a. Uji Koefisien Determinasi}

Koefisien korelasi ialah pengukuran statistik kovarian atau asosiasi antara dua variabel. Besarnya koefisien korelasi berkisar antara -1 dan +1 . Koefisien korelasi menunjukkan

Tabel 3. Kriteria Hubungan Kekuatan

\begin{tabular}{ll}
\hline Skala & Keterangan \\
\hline 0 & Tidak ada korelasi antar variabel \\
$>0-0.25$ & Korelasi sangat lemah \\
$>0.25-0.5$ & Korelasi cukup \\
$>0.5-0.75$ & Korelasi kuat \\
$>0.75-0.99$ & Korelasi sangat kuat \\
1 & Korelasi sempurna \\
\hline
\end{tabular}

kekuatan (strength) hubungan linear dan arah hubungan dua variabel acak. Berikut adalah kriteria hubungan kekuatan antara dua variabel (Sarwono, 2012): b. Uji Koefisien Determinasi $\left(\mathrm{R}^{2}\right)$

Menurut Ghozali (2018), uji koefisien determinasi $\left(\mathrm{R}^{2}\right)$ pada intinya mengukur seberapa jauh kemampuan model dalam menerangkan variasi variabel dependen. Nilai koefisien determinasi adalah antara nol dan satu.

\section{c. Uji Signifikansi Simultan (Uji Statistik F)}

Uji Statistik F pada dasarnya bertujuan untuk mengetahui apakah variabel independen secara bersamasama atau joint mempengaruhi variabel dependen (Ghozali, 2018). Kriteria pengambilan keputusan untuk uji statistik $F$ yang digunakan dalam penelitian ini adalah sebagai berikut: Quick look: Bila nilai F lebih besar daripada 4 maka Ho dapat ditolak pada derajat kepercayaan 5\% (dasar pengambilan keputusan pada tingkat signifikansi $5 \%$ atau 0,05 ) dan Ha diterima. Sehingga semua variabel independen secara serentak dan signifikan mempengaruhi variabel dependen (Ghozali, 2018).

\section{d. Uji Signifikansi Parameter}

\section{Individual (Uji Statistik t)}

Uji statistik $t$ pada dasarnya menunjukkan seberapa jauh pengaruh satu variabel independen secara individual dalam menerangkan variasi variabel dependen. Cara melakukan uji $\mathrm{t}$ adalah dengan kriteria pengujian hipotesis dengan menggunakan uji 
statistik $\mathrm{t}(p$ value $)<0,05$ maka hipotesis alternatif (Ha) diterima, 4. HASIL \& ANALISIS

yang menyatakan bahwa suatu 4.1 Objek Penelitian

variabel independen secara

Berikut adalah tabel rincian individual dan signifikan pengambilan sampel penelitian:

mempengaruhi variabel dependen

(Ghozali, 2018).

Tabel 4. Sampel dan Tingkat Pengembalian Kuesioner

\begin{tabular}{llll}
\hline No. & Keterangan & Jumlah & Persentase \\
\hline 1 & Jumlah kuesioner yang disebar & 120 & $100 \%$ \\
2 & Kuesioner yang tidak kembali & 8 & $6,67 \%$ \\
3 & Kuesioner yang kembali & 112 & $93,33 \%$ \\
4 & Kuesioner yang dapat digunakan & 112 & $93,33 \%$ \\
\hline
\end{tabular}

\subsection{Statistik Deskriptif}

Tabel 5. Analisis Statistik Deskriptif

\begin{tabular}{|l|r|r|r|r|r|r|}
\hline & D & Ranqe & Minimum & Maximum & Mean & Std. Deviation \\
\hline T_PEF & 112 & 4 & 11 & 15 & 12.74 & 1.105 \\
T_PKG & 112 & 8 & 12 & 20 & 16.96 & 1.919 \\
T_PKE & 112 & 9 & 21 & 30 & 25.25 & 2.296 \\
T_KK & 112 & 7 & 18 & 25 & 20.21 & 1.075 \\
T_KTI & 112 & 4 & 11 & 15 & 12.42 & .955 \\
T_KEP & 112 & 15 & 35 & 50 & 41.38 & 2.675 \\
Valid N (listwise) & 112 & & & & \\
\hline
\end{tabular}

Terdapat jumlah responden (N) sebanyak 112 orang. Rata rata (mean) dari variabel penggunaan $e$ Filing 12,74. Rata-rata untuk ketiga indikator dari variabel penggunaan $e$ Filing adalah sebesar 4,25 yang berarti bahwa Wajib Pajak setuju akan selalu menggunakan e-Filing dalam pelaporan perpajakannya, menggunakan e-Filing di masa depan karena mempunyai fitur yang membantu pekerjaan Wajib Pajak.
Variabel persepsi kegunaan rata-rata (mean) 16,96. Nilai rata-rata untuk keempat indikator dari variabel persepsi kegunaan adalah sebesar 4,24 yang berarti Wajib Pajak setuju bahwa penggunaan e-Filing akan meningkatkan performa, efektivitas, serta menyederhanakan pelaporan pajak, dan meningkatkan produktivitas Wajib Pajak dalam melaksanakan kewajiban perpajakannya. 
Analisis Faktor-Faktor yang Mempengaruhi Penggunaan E-Filing Oleh Wajib Pajak (Studi pada Wajib Pajak Orang Pribadi yang Terdaftar pada KPP Madya dan Pratama di Kota Tangerang dan Tangerang Selatan)

Variabel persepsi kemudahan memiliki nilai rata-rata (mean) 25,25 . Nilai rata-rata untuk keenam indikator dari variabel persepsi kemudahan adalah sebesar 4,21 yang berarti Wajib Pajak setuju bahwa sistem e-Filing mudah dipelajari, dapat berinteraksi dengan jelas dan terpahami, mudah digunakan, mudah beradaptasi, mudah untuk menjadi terampil, dan secara keseluruhan mudah digunakan.

Variabel independen keamanan dan kerahasiaan (KK) memiliki nilai rata-rata (mean) 20,21. Nilai rata-rata untuk kelima indikator dari variabel keamanan dan kerahasiaan adalah sebesar 4,04 yang berarti Wajib Pajak setuju bahwa sistem e-Filing aman, dapat memberikan tingkat jaminan kerahasiaan yang tinggi, dapat menjaga kerahasiaan, tidak khawatir dengan masalah keamanan e-Filing, dan permasalahan tingkat keamanan dan kerahasiaan dalam $e$ Filing tidak mempengaruhi Wajib Pajak dalam memanfaatkan layanan pelaporan pajak.

Variabel kesiapan teknologi informasi memiliki nilai rata-rata (mean) 12,42. Nilai rata-rata untuk ketiga indikator dari variabel kesiapan teknologi informasi adalah sebesar 4,14 yang berarti bahwa Wajib Pajak setuju bahwa koneksi internet dalam penggunaan e-Filing tersedia dengan baik, hardware dan software tersedia dengan baik dan SDM atau Wajib Pajak paham akan teknologi dalam penggunaan $e$ Filing.

Variabel kepuasan pengguna memiliki nilai rata-rata (mean) 41,38. Nilai rata-rata untuk kesepuluh indikator dari variabel kepuasan pengguna adalah sebesar 4,14 yang berarti Wajib Pajak setuju bahwa sistem e-Filing dapat membantu Wajib Pajak melakukan pelaporan secara efisien, melakukan pelaporan SPT tepat waktu, menghemat biaya dan energi saat menggunakan e-Filing untuk melaporkan SPT, Wajib Pajak merasa puas dengan pelayanan dan informasi yang dihasilkan sistem $e$ Filing, menyenangkan, dan memiliki perasaan bangga setelah menggunakan sistem $e$-Filing . 


\subsection{Uji Kualitas Data}

\subsubsection{Uji Validitas}

Tabel 6. Hasil Uji Validitas

\begin{tabular}{lll}
\hline Variabel & Signifikansi & Kesimpulan \\
\hline Persepsi kegunaan (PKG) & 0,000 & Valid \\
Persepsi kemudahan (PKE) & 0,000 & Valid \\
Keamanan dan kerahasiaan (KK) & 0,000 & Valid \\
Kesiapan teknologi informasi (KTI) & 0,000 & Valid \\
Kepuasan pengguna (KEP) & 0,000 & Valid \\
Penggunaan $e$-Filing (PEF) & 0,000 & Valid \\
\hline
\end{tabular}

Dari hasil uji validitas yang memiliki sig (2-tailed) sebesar 0,000 dilakukan, variabel penggunaan $e^{-} \quad$ atau $<0,05$. Hal ini menunjukkan Filing, persepsi kegunaan, persepsi bahwa semua pernyataan pada kemudahan, kepuasan, keamanan variabel dependen dan independen dan kerahasiaan, kesiapan teknologi telah dinyatakan valid.

informasi, dan kepuasan pengguna

\subsubsection{Uji Reliabilitas}

Tabel 8. Hasil Uji Reliabilitas

\begin{tabular}{ll}
\hline Variabel & Crobach's Alpha \\
\hline Persepsi kegunaan (PKG) & 0,845 \\
Persepsi kemudahan (PKE) & 0,925 \\
Keamanan dan kerahasiaan (KK) & 0,799 \\
Kesiapan teknologi informasi (KTI) & 0,757 \\
Kepuasan pengguna (KEP) & 0,825 \\
Penggunaan $e$-Filing (PEF) & 0,716 \\
\hline
\end{tabular}

Berdasarkan hasil uji reliabilitas yang dilakukan, dapat diketahui bahwa kuesioner penelitian dikatakan reliable, karena seluruh variabel yang digunakan yaitu Persepsi Kegunaan, Persepsi
Kemudahan, Keamanan dan Kerahasiaan, Kesiapan Teknologi Informasi, Kepuasan Pengguna, dan Penggunaan e-Filing memiliki nilai Cronbach's Alpha $>0,70$.

\subsubsection{Uji Normalitas}


Analisis Faktor-Faktor yang Mempengaruhi Penggunaan E-Filing Oleh Wajib Pajak (Studi pada Wajib Pajak Orang Pribadi yang Terdaftar pada KPP Madya dan Pratama di Kota Tangerang dan Tangerang Selatan)

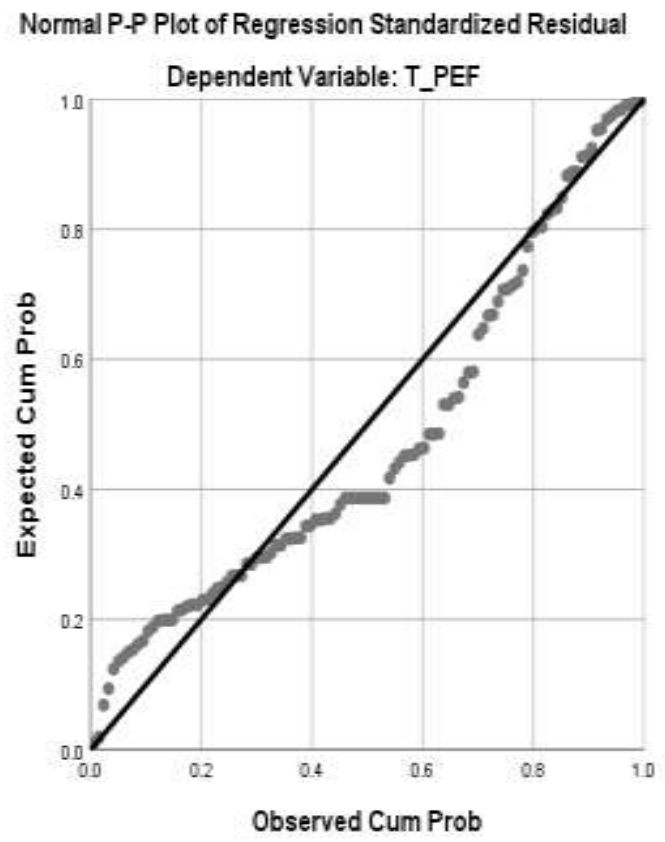

Gambar 4. Analisis Uji Normalitas

Berdasarkan Gambar 4 dapat dilihat bahwa dari normal probability plot bahwa penyebaran data mendekati garis diagonal.

\subsection{Uji Asumsi Klasik}

\subsubsection{Uji Multikolonieritas}

Tabel 9. Hasil Uji Multikolonieritas

\begin{tabular}{llll}
\hline \multirow{2}{*}{ Model } & \multicolumn{2}{c}{ Collinearity } & Statistics \\
& Tolerance & VIF \\
\hline 1 & (Constant) & .649 & 1.540 \\
T_PKG & .730 & 1.370 \\
& T_PKE & .869 & 1.150 \\
T_KK & .940 & 1.064 \\
T_KTI & .813 & 1.230 \\
& T_KEP & & \\
\hline
\end{tabular}

Berdasarkan Tabel 9 dapat dilihat bahwa semua variabel independen memiliki nilai tolerance diatas 0,10 dan nilai VIF kurang dari 10 sehingga dapat disimpulkan bahwa dalam penelitian ini tidak terjadi multikolonieritas antar variabel independen.

\subsubsection{Uji Heteroskedastisitas}




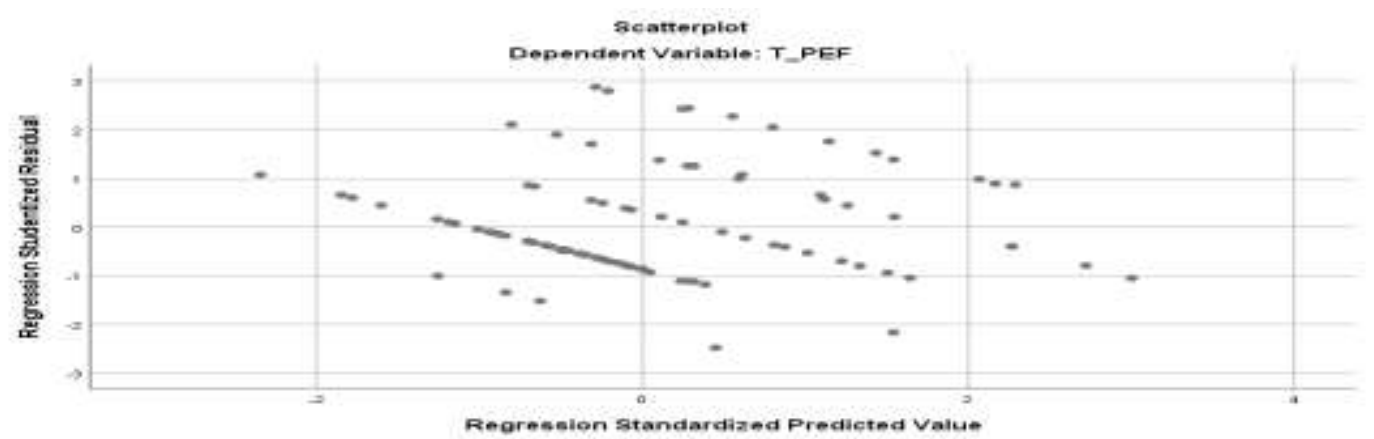

Gambar 5. Scatterplot

Berdasarkan Gambar 5 menunjukkan bahwa titik-titik pada grafik scatterplot tidak membentuk pola tertentu. Titik-titik menyebar secara acak baik di atas maupun di bawah angka 0 pada sumbu Y. Sehingga, dapat disimpulkan bahwa pada model regresi dalam penelitian ini tidak terjadi heteroskedastisitas.

\subsection{Uji Hipotesis}

\subsubsection{Uji Koefisien Determinasi $\left(\mathbf{R}^{2}\right)$}

Tabel 10. Hasil Uji Koefisien Determinasi

Model Summary ${ }^{b}$

\begin{tabular}{|c|c|c|c|c|}
\hline Model & $\mathrm{R}$ & R Square & $\begin{array}{l}\text { Adjusted } \\
\text { Square }\end{array}$ & $\begin{array}{l}\text { R Std. Error of } \\
\text { the Estimate }\end{array}$ \\
\hline 1 & $.634^{\mathrm{a}}$ & 402 & .374 & .874 \\
\hline
\end{tabular}

a. Predictors: (Constant), T_KEP, T_KTI, T_KK, T_PKE, T_PKG

b. Dependent Variable: T_PEF

Dari hasil pengujian koefisien kemudahan, keamanan dan determinasi berdasarkan Tabel 10, kerahasiaan, kesiapan teknologi nilai koefisien korelasi (R) dalam informasi, dan kepuasan pengguna penelitian ini adalah sebesar 0,634. dengan variabel dependen yaitu Hal ini menunjukkan bahwa penggunaan e-Filing berkolerasi hubungan antar variabel independen cukup karena nilai koefisien korelasi yaitu persepsi kegunaan persepsi $\quad(\mathrm{R})$ berada dalam klasifikasi kuat 
Analisis Faktor-Faktor yang Mempengaruhi Penggunaan E-Filing Oleh Wajib Pajak (Studi pada Wajib Pajak Orang Pribadi yang Terdaftar pada KPP Madya dan Pratama di Kota Tangerang dan Tangerang Selatan)

karena nilai koefisien korelasi $(\mathrm{R})$ berada dalam klasifikasi 0,5 sampai dengan 0,75 .

Dari hasil pengujian koefisien determinasi dapat dilihat dari nilai Adjusted $R$ Square sebesar 0.374. Hasil ini mengidentifikasikan bahwa secara statistik variabel dependen (penggunaan e-Filing) dapat dijelaskan oleh variasi dari variabel independen (persepsi kegunaan persepsi kemudahan, keamanan dan kerahasiaan, kesiapan teknologi informasi, dan kepuasan pengguna) adalah sebesar $37,4 \%$ dan sisanya $62,6 \%$ dijelaskan oleh variabel independen lainnya yang tidak digunakan dalam penelitian ini.

\subsubsection{Uji Signifikansi Simultan (Uji Statistik F)}

Tabel 11. Uji ANOVA

ANOVA $^{\mathrm{a}}$

\begin{tabular}{|ll|l|l|l|l|l|}
\hline \multicolumn{2}{|l|}{ Model } & $\begin{array}{l}\text { Sum } \\
\text { Squares }\end{array}$ & df & Mean Square & F & Sig. \\
\hline 1 & $\begin{array}{l}\text { Regression } \\
\text { Residual }\end{array}$ & 54.460 & 5 & 10.892 & 14.248 & $.000^{\mathrm{b}}$ \\
& \begin{tabular}{l} 
Total \\
\cline { 2 - 5 }
\end{tabular} & 135.491 & 111 & .764 & & \\
\hline
\end{tabular}

a. Dependent Variable: T_PEF

b. Predictors: (Constant), T_KEP, T_KTI, T_KK, T_PKE, T_PKG

\section{Hasil Uji Signifikansi Simultan} (Uji F)

Berdasarkan hasil uji $\mathrm{F}$ dapat dilihat pada Tabel 11, nilai F sebesar 14,248 dengan nilai signifikansi sebesar 0,000 atau lebih kecil dari 0,05. Hasil pengujian ini dapat diartikan bahwa secara bersama-sama atau secara simultan seluruh variabel independen yang terdiri dari persepsi kegunaan, persepsi kemudahan, keamanan dan kerahasiaan, kesiapan teknologi informasi, dan kepuasan pengguna.

\subsubsection{Uji Signifikansi Parameter Individual (Uji Statistik t)}

Tabel 12. Hasil Uji Signifikansi Parameter Individual (Uji t) 


\section{Coefficients $^{\mathrm{a}}$}

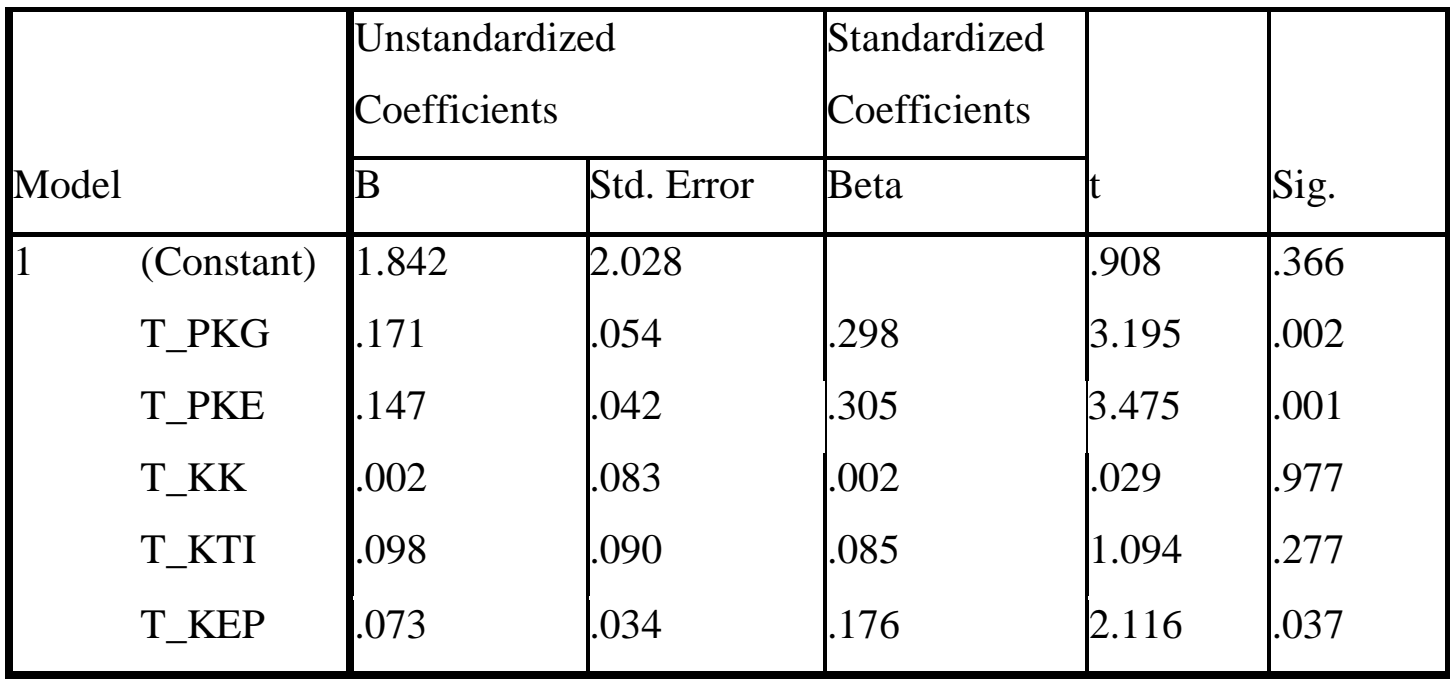

Dari hasil pengujian yang dilakukan, dari penelitian ini, yaitu sebagai maka dapat dibuat persamaan regresi berikut:

\section{PEF $=1,842+$ 0,171 PKG + 0,147 PKE + 0,002 KK + 0,098 KTI + 0,073 KEP}

Dari persamaan regresi yang kenaikan satu satuan persepsi dihasilkan, dapat disimpulkan bahwa kegunaan akan menyebabkan variabel persepsi kegunaan, persepsi peningkatan penggunaan e-Filing kemudahan, keamanan dan sebesar 0,171 atau sebesar 17,1\%. kerahasiaan, kesiapan teknologi informasi, dan kepuasan pengguna memiliki hubungan positif terhadap penggunaan $e$-Filing. Hubungan positif ini dapat dilihat dari PKG sebesar 0,171; PKE sebesar 0,147; KK sebesar 0,002; KTI sebesar 0,098 dan KEP sebesar 0,073.

Berdasarkan Tabel 12 hasil uji statistik t diperoleh koefisien regresi sebesar 0,171 untuk variabel persepsi kegunaan. Oleh karena itu, setiap Uji statistik $\mathrm{t}$ menunjukkan nilai $\mathrm{t}$ sebesar 3,195 dengan nilai signifikansi sebesar 0,002 atau < 0,05. Hasil penelitian ini menunjukkan bahwa $\mathrm{Ha}_{1}$ diterima sehingga dapat disimpulkan bahwa persepsi kegunaan berpengaruh terhadap penggunaan e-Filing. Hasil penelitian ini mendukung penelitian yang dilakukan oleh Herawan dan Waluyo (2014) yang menyatakan persepsi kegunaan berpengaruh 
Analisis Faktor-Faktor yang Mempengaruhi Penggunaan E-Filing Oleh Wajib Pajak (Studi pada Wajib Pajak Orang Pribadi yang Terdaftar pada KPP Madya dan Pratama di Kota Tangerang dan Tangerang Selatan)

signifikan terhadap penggunaan $e$ Filing.

Berdasarkan Tabel 12 hasil uji statistik $\mathrm{t}$ diperoleh koefisien regresi sebesar 0,147 untuk variabel persepsi kemudahan. Oleh karena itu, setiap kenaikan satu satuan persepsi kemudahan akan menyebabkan peningkatan penggunaan e-Filing sebesar 0,147 atau sebesar $14,7 \%$.

Uji statistik $\mathrm{t}$ menunjukkan nilai $\mathrm{t}$ sebesar 3,475 dengan nilai signifikansi sebesar 0,001 atau < 0,05. Hasil penelitian ini menunjukkan bahwa $\mathrm{Ha}_{2}$ diterima sehingga dapat disimpulkan bahwa persepsi kemudahan berpengaruh terhadap penggunaan $e$-Filing. Hasil penelitian ini mendukung penelitian yang dilakukan oleh Utami dan Osesoga (2017) yang menyatakan persepsi kemudahan penggunaan berpengaruh positif terhadap penggunaan $e$-Filing.

Berdasarkan Tabel 12 hasil uji statistik t diperoleh koefisien regresi sebesar 0,002 untuk variabel keamanan dan kerahasiaan. Oleh karena itu, setiap kenaikan satu satuan keamanan dan kerahasiaan akan menyebabkan peningkatan penggunaan e-Filing sebesar 0,002 atau sebesar 0,2\%. Uji statistik t menunjukkan nilai $\mathrm{t}$ sebesar 0,029 dengan nilai signifikansi sebesar 0,977 atau > 0,05. Hasil penelitian ini menunjukkan bahwa $\mathrm{Ha}_{3}$ ditolak sehingga dapat disimpulkan bahwa keamanan dan kerahasiaan tidak berpengaruh terhadap penggunaan $e$ Filing. Hasil penelitian ini mendukung penelitian yang dilakukan oleh Utami dan Osesoga (2017) dan Wahyuni (2015) yang menyatakan bahwa keamanan dan kerahasiaan tidak berpengaruh terhadap penggunaan e-Filing. Hal tersebut dilihat dari rata-rata responden yang menjawab setuju (4) sebesar 93 untuk indikator kelima dari variabel keamanan dan kerahasiaan yaitu permasalahan tingkat keamanan dan kerahasiaan dalam e-Filling tidak mempengaruhi saya dalam memanfaatkan layanan pelaporan pajak yang berarti bahwa responden akan tetap menggunakan sistem $e$-Filing tanpa memperdulikan tingkat keamanan dan kerahasiaan sistem tersebut.

Berdasarkan Tabel 12 hasil uji statistik $\mathrm{t}$ diperoleh koefisien regresi sebesar 0,098 untuk variabel kesiapan teknologi informasi. Oleh 
karena itu, setiap kenaikan satu satuan kesiapan teknologi informasi akan menyebabkan peningkatan penggunaan e-Filing sebesar 0,098 atau sebesar 9,8\%. Uji statistik $\mathrm{t}$ menunjukkan nilai $\mathrm{t}$ sebesar 1,094 dengan nilai signifikansi sebesar 0,277 atau > 0,05. Hasil penelitian ini menunjukkan bahwa $\mathrm{Ha}_{4}$ ditolak sehingga dapat disimpulkan bahwa kesiapan teknologi informasi tidak berpengaruh terhadap penggunaan $e$ Filing. Hasil penelitian ini mendukung penelitian yang dilakukan oleh Devina dan Waluyo (2016) yang menyatakan bahwa kesiapan teknologi informasi Wajib Pajak tidak berpengaruh terhadap penggunaan e-Filing. Hal tersebut dilihat dari rata-rata jawaban responden yang menjawab setuju (4) untuk ketiga indikator kesiapan teknologi informasi yang berarti responden telah memiliki koneksi internet, software dan hardware, dan SDM yang paham akan teknologi namun tetap tidak mendorong Wajib Pajak untuk menggunakan e-Filing. Kesiapan teknologi informasi tidak berpengaruh dengan penggunaan $e$ Filing karena Wajib Pajak tidak siap menerima perkembangan teknologi yaitu sistem e-Filing. Namun terbatasnya indikator variabel kesiapan teknologi informasi dalam kuesioner yang digunakan membatasi analisis dalam penelitian ini.

Berdasarkan Tabel 12 hasil uji statistik t diperoleh koefisien regresi sebesar 0,073 untuk variabel kepuasan pengguna. Oleh karena itu, setiap kenaikan satu satuan kepuasan pengguna akan menyebabkan peningkatan penggunaan e-Filing sebesar 0,073 atau sebesar 7,3\%. Uji statistik $\mathrm{t}$ menunjukkan nilai $\mathrm{t}$ sebesar 2,116 dengan nilai signifikansi sebesar 0,037 atau lebih kecil dari 0,05. Hasil penelitian ini menunjukkan bahwa $\mathrm{Ha}_{5}$ diterima sehingga dapat disimpulkan bahwa kepuasan pengguna berpengaruh terhadap penggunaan $e$-Filing. Hasil penelitian ini mendukung penelitian yang dilakukan oleh Maryani (2016) yang menyatakan bahwa kepuasan pengguna berpengaruh secara signifikan terhadap penggunaan $e$ Filing bagi Wajib Pajak.

\section{KESIMPULAN}

\subsection{Simpulan}


Analisis Faktor-Faktor yang Mempengaruhi Penggunaan E-Filing Oleh Wajib Pajak (Studi pada Wajib Pajak Orang Pribadi yang Terdaftar pada KPP Madya dan Pratama di Kota Tangerang dan Tangerang Selatan)

Berdasarkan uraian yang ada, maka dapat disampaikan simpulan hasil penelitian ini, yaitu sebagai berikut:

1. Persepsi kegunaan berpengaruh terhadap penggunaan e-Filing, hal tersebut dibuktikan dengan hasil uji $\mathrm{t}$ yang dilakukan memperoleh koefisien regresi sebesar 0,171. Uji statistik $\mathrm{t}$ menunjukkan nilai $t$ sebesar 3,195 dengan nilai signifikansi sebesar 0,002 atau $<0,05$.

2. Persepsi kemudahan berpengaruh terhadap penggunaan e-Filing, hal tersebut dibuktikan dengan hasil uji $t$ yang dilakukan memperoleh koefisien regresi sebesar 0,147. Uji statistik $t$ menunjukkan nilai $\mathrm{t}$ sebesar 3,475 dengan nilai signifikansi sebesar 0,001 atau <0,05.

3. Keamanan dan kerahasiaan tidak berpengaruh terhadap penggunaan $e$-Filing, hal tersebut dibuktikan dengan hasil uji $\mathrm{t}$ yang dilakukan memperoleh koefisien regresi sebesar 0,002. Uji statistik $\mathrm{t}$ menunjukkan nilai $\mathrm{t}$ sebesar 0,029 dengan nilai signifikansi sebesar 0,977 atau > 0,05. Hal tersebut terjadi karena responden akan tetap menggunakan sistem e-Filing tanpa memperdulikan tingkat keamanan dan kerahasiaan sistem tersebut.

4. Kesiapan Teknologi Informasi tidak berpengaruh terhadap penggunaan $e$-Filing, hal tersebut dibuktikan dengan hasil uji $\mathrm{t}$ yang dilakukan memperoleh koefisien regresi sebesar 0,098. Uji statistik t menunjukkan nilai $\mathrm{t}$ sebesar 1,094 dengan nilai signifikansi sebesar 0,277 atau > 0,05. Hal ini terjadi karena Wajib Pajak tidak siap menerima perkembangan teknologi yaitu $e$ Filing.

5. Kepuasan Pengguna berpengaruh terhadap penggunaan e-Filing, hal tersebut dibuktikan dengan hasil uji $t$ yang dilakukan memperoleh koefisien regresi sebesar 0,073. Uji statistik $t$ menunjukkan nilai $\mathrm{t}$ sebesar 2,116 dengan nilai signifikansi sebesar 0,037 atau $<0,05$.

Persepsi kegunaan, persepsi kemudahan, keamanan dan kerahasiaan, kesiapan teknologi informasi, dan kepuasan pengguna berpengaruh secara simultan terhadap penggunaan e-Filing, hal 
tersebut dibuktikan dengan hasil uji $F$ menunjukkan nilai $F$ sebesar 14,248 dengan nilai signifikansi sebesar 0,000 atau lebih kecil dari 0,05 .

Dari penelitian ini dapat disimpulkan bahwa faktor-faktor yang mempengaruhi penggunaan e-Filing adalah faktor penerimaan individu terhadap suatu teknologi yang terdiri dari persepsi kegunaan, persepsi kemudahan, dan kepuasan pengguna. Untuk meningkatkan penggunaan $e$ Filing maka Direktorat Jenderal Pajak harus meningkatkan produktivitas dan kemudahan saat penggunaan e-Filing agar Wajib Pajak memiliki pengalaman yang menyenangkan saat penggunaan $e$ Filing sehingga Wajib Pajak puas saat menggunakan $e$-Filing .

\subsection{Keterbatasan}

Berikut ini merupakan beberapa hal yang menjadi keterbatasan dalam penelitian ini, yaitu:

1. Penelitian ini hanya dilakukan di kota Tangerang dan Tangerang Selatan dan responden dalam penelitian ini seluruhnya adalah Wajib Pajak Orang Pribadi karyawan, sehingga hasil penelitian dianggap kurang mewakili Wajib Pajak yang menggunakan e-Filing atau dengan kata lain tidak dapat digeneralisasi.

2. Pilihan dalam pertanyaan lama penggunaan $e$-Filing berpotensi membingungkan responden dalam memilih jawaban yang tepat.

3. Dalam penelitian ini hanya mempertimbangkan lima variabel yaitu persepsi kegunaan, persepsi kemudahan, keamanan dan kerahasiaan, kesiapan teknologi informasi, dan kepuasan pengguna yang dapat dijelaskan oleh variasi variabel independen adalah sebesar $37,4 \%$ dan sisanya sebesar $62,6 \%$ dijelaskan oleh variabel independen lainnya yang tidak dijelaskan dalam penelitian sehingga kurang mewakili faktorfaktor yang mempengaruhi penggunaan e-Filing bagi Wajib Pajak.

\subsection{Saran}

Berdasarkan simpulan dan keterbatasan yang terdapat dalam penelitian ini, maka terdapat 
Analisis Faktor-Faktor yang Mempengaruhi Penggunaan E-Filing Oleh Wajib Pajak (Studi pada Wajib Pajak Orang Pribadi yang Terdaftar pada KPP Madya dan Pratama di Kota Tangerang dan Tangerang Selatan)

beberapa saran yang ditujukan

kepada penelitian selanjutnya:

\section{DAFTAR PUSTAKA}

1. Memperluas ruang lingkup wilayah penelitian atau mencoba daerah lain, memperluas cakupan objek penelitian seperti usahawan, pekerja lepas, pegawai negeri, dan menambah jumlah sebaran kuesioner selain Wajib Pajak yang bekerja di PT Matahari Department Store Tbk, Starlet Hotel, dan PT Linkadata Citra Mandiri sehingga dapat menghasilkan gambaran yang lebih akurat.

2. Memperjelas pilihan jawaban dalam pertanyaan lama penggunaan $e$-Filing agar tidak membingungkan responden saat memilih jawaban.

3. Menambahkan faktor-faktor lain selain persepsi kegunaan, Andi dan Sari, Dara Novita. 2017. Faktor-Faktor Yang Mempengaruhi Minat Wajib Pajak Orang Pribadi Dalam Penggunaan E-Filing Pada KPP Pratama Serang. Fakultas Ekonomi dan Bisnis Universitas Sultan Ageng Tirtayasa. SAINS: Jurnal Manajemen dan Bisnis. Vol. X, No. 1, Desember 2017, Hal. 41-65. ISSN 2541-1047.

Bangkara, Rajendra Prasada, Mimba, Ni Putu Sri Harta. 2016. Pengaruh Perceived Usefulness Dan Perceived Ease Of Use Minat Penggunaan Internet Banking Dengan Attitude Toward Using Sebagai Variabel Intervening. Fakultas Ekonomi dan Bisnis Universitas Udayana (UNUD), Bali, Indonesia. EJurnal Akuntansi Universitas Udayana. Vol. 16, No. 3, September 2016, Hal. 24082434. ISSN 2302-8556.

persepsi kemudahan, keamanan dan kerahasiaan, kesiapan teknologi informasi, dan kepuasan pengguna yang memiliki kemungkinan berpengaruh terhadap penggunaan $e$-Filing bagi Wajib Pajak, seperti kecepatan, kerumitan, kesukarelaan, pengalaman, dan kualitas sistem. 
Daryatno, Andreas Bambang. 2017.

Faktor-Faktor Yang

Mempengaruhi Penggunaan

E-Filling Pada Wajib Pajak

Orang Pribadi Di Jakarta

Barat. Fakultas Ekonomi Universitas Tarumanegara.

Jurnal Muara Ilmu Ekonomi dan Bisnis. Vol. 1, No. 1, April 2017, Hal. 97-106. ISSN 2579-6224, ISSN-L 2579-6232.

Devina, Shelby \& Waluyo. 2016.

Pengaruh Persepsi Kegunaan,

Persepsi Kemudahan,

Kecepatan, Keamanan dan

Kerahasiaan Serta Kesiapan

Teknologi Informasi Wajib

Pajak terhadap Penggunaan $e$ -

Filing Bagi Wajib Pajak

Orang Pribadi Di Kota

Tangerang, Kecamatan

Karawaci. Universitas

Multimedia Nusantara.

Ultima Accounting. Vol. 8,

No.1, Juni 2016, Hal. 75-91.

ISSN 2085-4595.

Dewi, Putu Dessy Kurnia \& Noviari, Naniek. 2018. Faktor-Faktor

Yang Mempengaruhi

Intensitas Perilaku Dalam

Penggunaan E-Filing Pada

Wajib Pajak Orang Pribadi.

Fakultas Ekonomi dan Bisnis

Universitas Udayana

(UNUD), Bali, Indonesia. E-

Jurnal Akuntansi Universitas

Udayana. Vol. 22, No. 3,

Maret 2018, Hal. 2368-2398.

ISSN 2302-8556.
Dharma, I Wayan Hredaya \& Noviari, $\quad$ Naniek. 2016. Faktor-Faktor Yang Berpengaruh Pada Intensitas Perilaku Dalam Penggunaan E-Filing Oleh Wajib Pajak Orang Pribadi. Fakultas Ekonomi dan Bisnis Universitas Udayana (UNUD), Bali, Indonesia. EJurnal Akuntansi Universitas Udayana. Vol. 17, No. 2, November 2016, Hal. 13421370, ISSN 2302-8556.

Direktorat Jenderal Pajak. 2017. Annual Report DJP 2016.

Dyanrosi, Aulia. 2015. Analisis Perilaku Wajib Pajak Orang Pribadi Terhadap Minat Perilaku Menggunakan EFiling. Program Magister Ilmu Administrasi Bisnis, Universitas Brawijaya. JISIP: Jurnal Ilmu Sosial dan Ilmu Politik. Vol. 4, No. 2 (2015). ISSN 2442-6962.

Ghozali, Imam. 2018. Aplikasi Analisis Multivariate dengan Program IBM SPSS 25. Semarang: Badan Penerbit Universitas Diponegoro.

Herawan, Lavenia \& Waluyo. 2014. Analisis Faktor-Faktor yang Mempengaruhi Perilaku Wajib Pajak Terhadap Penggunaan E-filing. Universitas Multimedia Nusantara. Ultima Accounting. Vol. 6, No. 2, Desember 2014, Hal. 77-96. ISSN 2085-4595. 
Analisis Faktor-Faktor yang Mempengaruhi Penggunaan E-Filing Oleh Wajib Pajak (Studi pada Wajib Pajak Orang Pribadi yang Terdaftar pada KPP Madya dan Pratama di Kota Tangerang dan Tangerang Selatan)

Ilyas, Wirawan B dan Burton, Richard. 2013. Hukum Pajak: Teori, Analisis dan Perkembangannya. Jakarta: Salemba Empat.

Kolompoy, Calvin, Hat, Ventje \& Sabijono, Harijanto. 2015. Pengaruh Perilaku Individu Wajib Pajak Orang Pribadi Terhadap Penggunaan EFiling di Kota Manado. Fakultas Ekonomi dan Bisnis Universitas Sam Ratulangi. Jurnal Accountability. Vol. 4, No. 2, Desember 2015, Hal. 52-58. ISSN 2338-3917.

Laihad, Risal C. Y. 2013. Pengaruh Perilaku Wajib Pajak Terhadap Penggunaan EFiling Wajib Pajak di Kota Manado. Universitas Sam Ratulangi Manado. Jurnal EMBA. Vol. 1, No. 3, September 2013, Hal. 44-51. ISSN 2303-1174.

Maryani, Ay. 2016. Faktor-Faktor Yang Mempengaruhi Penggunaan E-Filing: Studi Pada UIN Syarif Hidayatullah Jakarta. Universitas Islam Negeri Syarif Hidayatullah. Akuntabilitas: Jurnal Ilmu Akuntansi. Vol. 9, No. 2, Oktober 2016, Hal. 161-172. P-P-ISSN 1979-858X, EISSN 2461-1190.
Mujiyati, Karmila, \& Wahyuningtyas, Septiyara. 2016. Faktor-Faktor Yang Mempengaruhi Penggunaan E-Filling Wajib Pajak Orang Pribadi. Program Studi Akuntansi Fakultas Ekonomi dan Bisnis, Universitas Muhammadiyah Surakarta. Seminar Nasional dan The 3rd Call for Syariah Paper. Mei 2016, Hal. 419-430. ISSN 2460-0784.

Muzzamil, Choerul \& Budiarto, Astrid. 2016. Pedoman Praktis Membayar Pajak. Edisi 1. Yogyakarta: Genesis Learning.

Nurhasanah, Firmansyah \& Novrida, Ima. 2015. Pengaruh Persepsi Wajib Pajak Orang Pribadi terhadap Penggunaan Electronic Filing (e-filing) di KPP Pratama Palembang Ilir Barat. Jurusan Akuntansi Politeknik Negeri Sriwijaya. Jurnal Akuntanika. Vol. 1, No. 1, Januari-Juni 2015, Hal. 1-12. ISSN 2407-1072.

Nurjannah. 2017. Pengaruh Persepsi Kebermanfaatan, Persepsi Kemudahan, Kepuasan, Kecepatan, Keamanan dan Kerahasiaan Terhadap Penggunaan Fasilitas $E$ Filing Sebagai Sarana Penyampaian SPT Masa Secara Online Dan Realtime Bagi Wajib Pajak Badan Di Dumai. Faculty of Economic Riau University, Pekanbaru, Indonesia. JOM FEKON. Vol. 4, No. 1, Februari 2017, Hal. 1828-1842. ISSN 23556854. 
Pawirosumarto, Suharno. Katidjan, Purwanto S. \& Mulyanto, Angga Dwi. 2015. Pengaruh Computer Self Efficacy Terhadap Kualitas Sistem, Kualitas Informasi, Kualitas Layanan, Penggunaan, Kepuasan Pengguna, Dan Dampak Individu. Dosen Program Magister Manajemen, Pascasarjana, Universitas Mercu Buana, Jakarta dan Mahasiswa S2 Program Statistika Universitas Brawijaya, Malang. Jurnal MIX. Vol. VI, No, 2, Juni 2015, Hal. 310327. ISSN 2460-5328.

Peraturan Direktur Jenderal Pajak Nomor PER-01/PJ/2016 tentang Tata Cara Penerimaan dan Pengolahan Surat Pemberitahuan

Peraturan Direktur Jenderal Pajak Nomor PER-01/PJ/2017 tentang Penyampaian Surat Pemberitahuan Elektronik

Peraturan Menteri Keuangan Republik Indonesia Nomor 9/PMK.03/2018 tentang Perubahan Atas Peraturan Menteri Keuangan Nomor 243/PMK.03/2014 tentang Surat Pemberitahuan

Peraturan Menteri Keuangan Republik Indonesia Nomor 243/PMK.03/2014 tentang Surat Pemberitahuan

Resmi, Siti. 2017. Perpajakan: Teori dan Kasus (Buku 1) Edisi 8. Jakarta: Salemba Empat.
Romney \& Steinbart, Paul John. 2018. Accounting Information Systems $14^{\text {th }}$ Edition. United States of America: Pearson.

Salim, Emil. 2013. Faktor-Faktor yang Mempengaruhi Penggunaan Fasilitas $e$-Filing oleh Wajib Pajak sebagai Sarana Penyampaian SPT Masa secara Online dan Realtime (Studi Empiris pada Wajib Pajak Badan di KPP Madya Jakarta Pusat). Jurnal Akuntansi. Fakultas Ekonomi. Sumatera Barat: Universitas Bung Hatta.

Saripah, Adriyanti. Putri, Agustina \& Darwin, Ranti. 2016. Pengaruh Kepercayaan, Persepsi Kebermanfaatan, Persepsi Risiko dan Kepuasan Wajib Pajak Terhadap Penggunaan e-filling bagi Wajib Pajak Orang Pribadi di KPP Pratama Pekanbaru Tampan Tahun 2015. Universitas Muhammadiyah Riau, Fakultas Ekonomi dan Bisnis, Pekanbaru, Indonesia. Jurnal Akuntansi dan Ekonomika. Vol. 6, No. 2, Desember 2016, Hal. 134149. ISSN 977-20817.

Sarwono, Jonathan. 2012. Mengenal SPSS Statistics 20: Aplikasi untuk Riset Eksperimental. Jakarta: Elex Media Komputindo.

Sekaran, Uma dan Roger Bougie. 2016. Research Methods for Business: a Skill Building Approach Seventh Edition. United Kingdom: John Wiley and Sons Ltd. 
Analisis Faktor-Faktor yang Mempengaruhi Penggunaan E-Filing Oleh Wajib Pajak (Studi pada Wajib Pajak Orang Pribadi yang Terdaftar pada KPP Madya dan Pratama di Kota Tangerang dan Tangerang Selatan)

Syah, Asrofi. Noerman, Langgeng \&

Widianto, Andri. 2017. Minat

Pelaporan SPT melalui $E$ Filling: Studi Kasus Pada KPP Pratama Tegal. Politeknik Harapan Bersama Tegal. Jurnal Media Riset Akuntansi, Auditing \& Informasi. Vol. 17, No. 1, April 2017, Hal. 81-96. ISSN Online 2442-9708, ISSN Print 1411-8831.

Syakura, Muhammad. Yoremia, Abadan, \& Ginting, Lestari. 2017. Perilaku Wajib Pajak terhadap Niat Menggunakan E-Filing dan Kepatuhan Wajib Pajak (Studi pada Wajib Pajak dengan Profesi sebagai Dosen). Fakultas Ekonomi dan Bisnis Universitas Mulawarman, Samarinda, Indonesia. Jurnal Akuntabel. Vol. 14, No. 1, 2017, Hal. 46-56. ISSN Print 0216-7743, ISSN Online 2528-1135.

Undang-Undang Republik Indonesia Nomor 28 Tahun 2007 Tentang Ketentuan Umum dan Tata Cara Perpajakan

Utami, Adisti Putri \& Osesoga, Maria Stefani. 2017. Analisis Faktor-Faktor Yang Mempengaruhi Penggunaan E-Filing Wajib Pajak Orang Pribadi. Universitas Multimedia Nusantara. Ultima Accounting. Vol. 9, No. 2, Desember 2017, Hal. 15-32. ISSN 2085-4595.
Wahyuni, Resky. 2015. Pengaruh Persepsi Kegunaan, Kemudahan, Keamanan dan Kerahasiaan, dan Kecepatan terhadap Intensitas Perilaku dalam Penggunaan E-Filing (Studi Pada Wajib Pajak Orang Pribadi di Kantor Pelayanan Pajak Pratama Pekanbaru Senapelan). Faculty of Economic Riau University, Pekanbaru, Indonesia. JOM FEKON. Vol. 2, No. 2, Oktober 2015. ISSN 2355-6854.

Waluyo. 2017. Perpajakan Indonesia (Buku 1) Edisi 12. Jakarta: Salemba Empat.

Wardani, Dewi Kusuma \& Ambarwati, Harum. 2017. Faktor-Faktor Yang Mempengaruhi Niat Wajib Pajak Untuk Menggunakan E-Filing. Universitas Sarjanawiyata Tamansiswa Yogyakarta. Jurnal Akmenika. Vol. 14, No. 2, Oktober 2017, Hal. 979-989. ISSN 1978-1679.

http://www.bppk.kemenkeu.go.id/ber ita-pajak/12649-tax-gapuntuk-mengukur-kinerjadirektorat-jenderal-pajak. Diakses tanggal 15 Mei 2017.

www.bps.go.id/subject/11/produkdomestik-bruto--lapanganusaha-.html. Diakses tanggal 22 April 2018

https://kbbi.kemdikbud.go.id/entri/pe rsepsi. Diakses tanggal 28 Mei 2018. 
https://www.kemenkeu.go.id/media/ 6552/informasi-apbn2018.pdf. Diakses tanggal 10 Mei 2018.

https://www.kemenkeu.go.id/informa si-publik/realisasi-apbn/. Diakses tanggal 10 Mei 2018.

https://www.kemenkeu.go.id/media/ 5995/lkpp-2013.pdf. Diakses tanggal 10 Mei 2018. https://nasional.kontan.co.id/news/di audit-bpk-tax-ratio-2017hanya-107. Diakses tanggal 6 Agustus 2018

http://www.pajak.go.id/e-filing Diakses tanggal 22 April 2018. 